\title{
Strategies and methods to study sex differences in cardiovascular structure and function: a guide for basic scientists
}

Virginia M Miller ${ }^{1 *}$, Jay R Kaplan², Nicholas J Schork ${ }^{3}$, Pamela Ouyang ${ }^{4}$, Sarah L Berga ${ }^{5}$, Nanette K Wenger ${ }^{6}$, Leslee J Shaw ${ }^{7}$, R Clinton Webb ${ }^{8}$, Monica Mallampalli ${ }^{9}$, Meir Steiner ${ }^{10}$, Doris A Taylor ${ }^{11}$, C Noel Bairey Merz $^{12}$ and Jane F Reckelhoff ${ }^{13}$

\begin{abstract}
Background: Cardiovascular disease remains the primary cause of death worldwide. In the US, deaths due to cardiovascular disease for women exceed those of men. While cultural and psychosocial factors such as education, economic status, marital status and access to healthcare contribute to sex differences in adverse outcomes, physiological and molecular bases of differences between women and men that contribute to development of cardiovascular disease and response to therapy remain underexplored.
\end{abstract}

Methods: This article describes concepts, methods and procedures to assist in the design of animal and tissue/cell based studies of sex differences in cardiovascular structure, function and models of disease.

Results: To address knowledge gaps, study designs must incorporate appropriate experimental material including species/strain characteristics, sex and hormonal status. Determining whether a sex difference exists in a trait must take into account the reproductive status and history of the animal including those used for tissue (cell) harvest, such as the presence of gonadal steroids at the time of testing, during development or number of pregnancies. When selecting the type of experimental animal, additional consideration should be given to diet requirements (soy or plant based influencing consumption of phytoestrogen), lifespan, frequency of estrous cycle in females, and ability to investigate developmental or environmental components of disease modulation. Stress imposed by disruption of sleep/wake cycles, patterns of social interaction (or degree of social isolation), or handling may influence adrenal hormones that interact with pathways activated by the sex steroid hormones. Care must be given to selection of hormonal treatment and route of administration.

Conclusions: Accounting for sex in the design and interpretation of studies including pharmacological effects of drugs is essential to increase the foundation of basic knowledge upon which to build translational approaches to prevent, diagnose and treat cardiovascular diseases in humans.

Keywords: animal models, estrogen, gender, genomics, sex chromosomes, sex steroid hormones, study design, testosterone

\section{Introduction}

There are significant disparities between women and men in the incidence of, and mortality from, cardiovascular disease [1-4]. Thus, there is a need for improvement in the current preventive, diagnostic and

\footnotetext{
* Correspondence: miller.virginia@mayo.edu

'Departments of Surgery, Physiology and Biomedical Engineering, Mayo

Clinic, 200 First Street SW, Rochester, MN, 55905, USA

Full list of author information is available at the end of the article
}

treatment strategies by accounting for sex-specific differences in the etiology and risk factors of cardiovascular disease. In 2001, the Institute of Medicine advocated that a better understanding of differences in human diseases between males and females, with translation of these differences into clinical practice, requires consideration of sex as an important biological variable in design of basic research [5]. Funding agencies in the US, Canada and the European Union require inclusion of 
women in governmental sponsored research and analyses of outcomes by sex [6-10]. Often, however, implementation of those requirements is not met. Even if the requirement is met, including men and women in clinical studies often does not advance the goal of understanding sex differences as there is no requirement to compare the sexes nor is there a requirement to sufficiently power studies to do so [11-15]. Furthermore, there are no requirements for inclusion of male and female animals in basic, mechanistic, or preclinical studies and often sex is not reported as a critical biological variable in the study design [16-18].

This paper is intended as a guide to help formulate hypothesis-driven studies of cardiovascular function accounting for sex as a biological variable. Design considerations for studies on sex differences of cardiovascular disease will be discussed to extend those which have been developed for studies of brain and behavior $[19,20]$, neuroprotection after stroke [21], and pain and analgesia [22]. Advantages and disadvantages of various cell/tissue culture systems and experimental animals (from transgenic mice to non-human primates) will be reviewed along with methods to differentiate sex-specific effects caused by various factors (for example, sex chromosomes and gonadal hormones). Questions are posed to direct investigators toward optimizing the choice of experimental system to maximize the information gained for translation to human medicine. Application of genetic studies including quantitative trait locus mapping will be evaluated in relationship to cardiovascular phenotypes of different model species. Finally, recommendations are provided for statistical analysis and future research directions. Accounting for sex in the design and interpretation of basic research of cardiovascular structure, function and disease is essential to achieve scientific excellence whether such studies utilize cultured cells, isolated tissues, or experimental animals $[23,24]$ and is essential to increase the foundation of basic knowledge upon which to build translational approaches to medical care of humans [25-28]. Information provided in this paper will help guide the investigator toward that excellence.

\section{Definitions}

Sex, a biological construct, gender, a psychosocial construct, and environment contribute to disparities in cardiovascular disease separately or through interactions. Studies using cells and tissues or experimental animals can be designed to identify these differences and interactions.

\section{Terminology related to sex steroid hormones}

'Sex', a biological construct, refers to biological differences defined by sex chromosomes (XX, XY) and the presence of functional reproductive organs and sex steroids $[5,19,20]$. Biological questions require identification of which cells, tissues and organs demonstrate dimorphic structure and function related to cardiovascular disease. 'Gender', a cultural construct, refers to behaviors thought to be directed by specific stimuli, such as olfaction, for example, or by psychosocial expectations that result or accrue on the basis of assigned or perceived sex. Thus, gender can influence biological outcomes. For example, in a society where one sex is devalued relative to the other, the devalued gender may experience increased stress through reduced autonomy or access to nutrition/water/sleep, or in the case of humans, access to medical resources, which may influence development of cardiovascular disease, diagnosis and subsequent treatment. Thus, sex is considered a dichotomous variable; gender is a continuous variable as defined by a range of characteristics that might vary with age, species (animals), or ethnicity (humans), geographical location, education, and culture. Most studies using animals categorized by anatomical features and chromosomes can be described as studies of 'sex differences', with identification of dimorphic cellular, tissue, or organ functions. However, studies using animals can also be designed to answer questions which address psychosocial constructs, such as whether hierarchical social interactions are biologically based and whether they influence biological imprinting, or vice versa, in relationship to cardiovascular disease.

What are sex steroid hormones?

As described above, sex is defined by the $\mathrm{XX}$ or $\mathrm{XY}$ chromosomal complement and the presence of sex organs and sex steroid hormones. Sex steroid hormones fall into three general classes of hormones: androgens, estrogens and progestogens. Intracellular and intranuclear actions of hormones belonging to these classes are mediated through binding of the hormones to specific receptors. Extensive reviews of the types and cellular mechanisms of action of these receptors are available [29-36].

Designing experiments in which one intends to evaluate effects of sex steroids on cardiovascular disease processes require the mention of certain caveats. First, hormones belonging to each of these classes are synthesized naturally in mammals. However, synthetic analogs of the naturally produced hormones are also available commercially. Most natural steroid hormones bind to only one class of intracellular receptor. For example, the naturally occurring estrogen, $17 \beta$-estradiol, binds only to estrogen receptors and not to an androgen or progesterone receptor, and naturally occurring progesterone binds only to the progesterone receptor. However, many synthetic steroids bind to multiple classes of steroid receptors. Thus, for example, it is important to distinguish synthetic progestogens from the natural hormone 
as they may differ in their affinity for progesterone and/ or glucocorticoid receptors or their antimineralocorticoid effects $[32,37,38]$. In addition, certain progestogens may bind to the androgen receptor. These may antagonize actions of endogenous androgens by reversibly binding to the androgen receptor but because these progestogens are 'weak androgens', their binding does not initiate the full cascade of intracellular actions such as translocation to the nucleus and initiation receptormediated DNA transcription [39-41]. This issue is of particular importance in evaluating effects of hormonal treatments (hormonally based contraception, oophorectomy and hormonal treatments, including those of selective estrogen receptor modulators (SERMS)) on cardiovascular function and disease.

A second consideration regarding studies utilizing sex steroid hormones is that of tissue production independent of primary sources. Although the primary source of production of androgens is the testes in males and the ovary for production of estrogens and progesterone in females, local steroidogenesis and possible production of steroids from 'precursor' compounds at the cell membrane or within the cytoplasm in non-sex organs may also occur. Thus, steroid exposure may occur on a tissue or cell level that is not reflected by measurement of circulating levels of sex steroids [42-46].

The third consideration regarding the evaluation of hormonal effects in design of studies investigating sex differences is that metabolic products of androgens and estrogens have biologic activity. The androgen, 5-dehydroepiandrosterone (DHEA) is synthesized from cholesterol in the adrenal gland, testes and ovaries. Testosterone, as well as five other androgens, is synthesized from DHEA. Testosterone can be aromatized to $17 \beta$-estradiol while the androgen, $5 \alpha$-dihydrotestosterone (DHT), cannot be aromatized. Therefore, for studies in which the investigator administers an androgen but does not want to risk increasing estradiol synthesis, DHT can be substituted for testosterone. However, DHT is more biologically active because it binds to the androgen receptor with a 15 -fold higher affinity than testosterone [31].

The primary estrogen produced by the human ovary is $17 \beta$-estradiol, but the term 'estrogen' encompasses metabolites of $17 \beta$-estradiol including estrone, estrone sulfate, estriol, ethinyl estradiol, as well as xenoestrogens. Because metabolites of $17 \beta$-estradiol are biologically active $[47,48]$, investigators must be specific about the hormone used in their studies as well as the mode of delivery. For example, because of a 'first pass' effect through the liver, oral $17 \beta$-estradiol is metabolized to estrone and estrone conjugates prior to distribution in the circulation whereas delivery of $17 \beta$-estradiol transdermally, subcutaneously, intramuscularly, or vaginally results in a physiological ratio of estradiol to estrone. In human females with intact ovaries during reproductive years, the ratio of $17 \beta$-estradiol to estrone is roughly $1: 1$ [49]. The adrenal glands also manufacture and secrete estradiol and estrone. Oral products through the 'first pass effect' also increase production of liver proteins, such as sex hormone-binding globulin (SHBG) and clotting factors, with attendant biological consequences.

Terminology is also important. For example, a mixture of conjugated estrogen metabolites derived from urine of pregnant mares (conjugated equine estrogen (CEE)), which contains primarily equilin sulfate and estrone sulfate (and other metabolites of estrogen, as well as androgens) was used in the Women's Health Initiative. Oral administration of this compound was used to determine effects of 'estrogen treatment' for primary prevention of cardiovascular disease in postmenopausal women. Publications from this trial refer to the effects of 'estrogen' but, in fact, are the effects of a mixture of steroid metabolites, and thus the findings may not be applicable to other specific estrogenic products delivered by other routes or to results of studies conducted in experimental animals where $17 \beta$-estradiol was administered subcutaneously [50-54].

\section{Design considerations and choice of experimental models} Choice of an experimental system will affect outcomes and should be considered carefully in design of experiments to evaluate sex differences in cardiovascular disease as many unanswered questions exist regarding whether sex differences in a particular phenotype are due to sex, hormones, or sex $\times$ hormone interactions at various life stages.

\section{Origins of sex differences}

All biological sex differences are initiated by the genes of the sex chromosomes, which are the only genes that are inherited in a sex-specific manner. Differences between XY and XX cells can be attributed to: (1) the presence of $Y$ genes only in male cells, (2) the presence of a higher dose of $\mathrm{X}$ genes in $\mathrm{XX}$ compared to $\mathrm{XY}$ cells with random $\mathrm{X}$-inactivation of one $\mathrm{X}$ chromosome in XX cells, (3) mixed maternal and paternal genomic imprint on $\mathrm{X}$ genes in XX cells, and/or (4) only maternal imprinting on $X$ genes in XY cells [19]. The SRY gene on the $\mathrm{Y}$ chromosome, which determines the development of the testis and the subsequent secretion of male sex hormones, also influences expression of other genes on the autosomal chromosomes. Sex hormones at critical periods in development influence cellular differentiation, which may also be influenced by environmental factors. Another way to frame these interactions is as hormone-independent sexual differentiation, hormone-dependent sexual differentiation and sex-specific hormone actions. Determining whether a 
trait or condition is a sex difference requires a systematic approach to separate the interactions of sex chromosomes, sex hormones and environment. A logical series of experimental questions that has been proposed for studies in brain and behavior [19] can serve as a guide for investigators in cardiovascular disease research as well. These are: (1) is there a sex difference in the trait/ phenotype? (2) Does the sex difference result from the hormonal status of the test system (cells in culture, isolated tissues or animals) at the time of testing? (3) Is the hormonal action specific to or modified by sex? (4) Does the sex difference result from permanent differentiating effects of gonadal hormones? (5) Is the sex difference due to genomic or non-genomic responses to the sex steroids? And (6) does the sex difference result from a sex chromosomal influence on autosomal gene expression?

\section{Choice of experimental systems}

The choice of an experimental system will depend on the question being asked and the hypothesis to be tested. In contemporary publishing, methodological details including the sex of the research material or animals are often omitted from research papers or relegated to supplementary material. However, it is just these methodological details that allow investigators to reproduce experiments of others and to understand how important variables such as sex or hormonal status may influence outcomes. The Institute for Laboratory Animal Research and their official publication (ILAR Journal) is a rich resource for details regarding reproductive, hormonal and developmental information of various animal species used in cardiovascular disease research. Several general considerations are provided below for some of the more common experimental systems employed to address mechanisms of cardiovascular function.

Cells in culture and isolated tissues Cultured vascular endothelial cells, smooth muscle cells and cardiac myocytes (including neonatal cells), as well as isolated blood vessels and hearts, are used in experiments that explore intracellular signaling mechanisms in the development and treatment of cardiovascular disease. While most signaling pathways may be common in cells/tissues derived from female and male animals, it is important to understand which pathways may or may not show a sex difference as gene and protein expressions are influenced by both sex and hormones [55-62]. The same can be said for stem and progenitor cells being cultured for cell-based therapies [63-66]. For example in mice, cells derived from female animals appear to be more effective at both reversing disease and restoring a pre-disease level of cells to bone marrow than male-derived cells [66]. Differences in the efficacy of male and female cells could possibly be attributed to differences in paracrine factors (for example, cytokines) [65]. Comparison of these preclinical vascular data to early human clinical data suggest that sex-based differences in progenitor cell numbers and function seen in mouse models of atherosclerosis and acute myocardial infarction reflect human clinical scenarios [64].

The following points should be addressed in design of experiments using cultured cells, isolated stem and progenitor cells, and isolated tissues: (1) is expression of the receptor, pathway, enzyme, and so on, or the number of isolated progenitor cells affected by the sex or hormonal status of the donor animal? For example, would gene expression/signaling differ depending on whether the donor animal was studied before sexual maturity, was sexually mature (null or multiparous), or was reproductively senescent? (2) Would number of cells, gene expression or phenotype be affected by gonadectomy of the donor either before or after sexual maturity? (3) How does the expression of the pathway of interest or phenotype of progenitor cells change with passage of cells exposed to hormones in culture media using fetal bovine serum? (4) Is the choice of cell/tissue donor appropriate for the mechanism of interest related to human disease in regard to sex, age and hormonal status? (5) For cell-based therapies, given potential sex differences in cell number, phenotype, and potency, should sex mismatched allogeneic cells be considered as a therapeutic option? If so, is the donor appropriate for the mechanism of interest related to human disease in regard to sex, age and hormonal status?

The age/hormonal status of the donor for cell/tissue may not be available depending on the source of the material (that is, abattoir, human material for which medical information/records are not available, some immortalized cell lines). If the sex of the cell/tissue donor is not known, it can be determined by a PCRbased assay to identify specific fragments of the $\mathrm{X}$ and $\mathrm{Y}$ chromosomes. For example, a multiplex PCR-based method was developed to measure a 475-bp fragment from the ABCD1 gene ( $\mathrm{X}$ chromosome) and a 231-bp fragment from the SRY gene (Y chromosome) [67]. This method has been refined and extended to a highthroughput automated setting [68].

Sex of neonatal animals (including mice and rats) can be determined by examining the anogenital distance [69]. In larger animals the presence of gonads should be confirmed as some male animals obtained from commercial suppliers (in particular, pigs) may be castrated at birth, and, therefore, studies in these animals would yield cells developed or differentiated under a sex hormone-depleted environment.

As sex differences are influenced both by the sex chromosomes and sex hormones, care must be taken to control the hormonal environment of cultured cells. Some media, in particular, fetal calf serum, contain sex 
steroid hormones that could influence the pathway/signal of interest. Media can be stripped of hormones by charcoal treatment. When hormones are added to the media, care should be taken to control for the solvent used for lipophilic compounds and to consider that both testosterone and $17 \beta$-estradiol may be metabolized by the tissue. Thus, a given concentration of sex steroid added at day 1 of a culture cycle may not be sustained over a long period of time. Alternatively, exposure of cells to hormones may 'imprint' the cell phenotype over several passages $[70,71]$. As sex steroid hormones initiate rapid actions that do not require gene transcription (non-genomic actions) as well as effects on gene transcription (genomic actions) that represent different temporal sequences, duration of exposure to the hormone of interest is a critical consideration in study design.

For example, prolonged exposure of certain cells to $17 \beta$ estradiol increases synthesis of endothelial nitric oxide synthase (eNOS) via a genomic mechanism caused by binding of the ligand-bound estrogen receptor $\alpha$ $(E R \alpha)$ to an estrogen response element (ERE) on the eNOS gene [37]. However, estradiol also acutely increases eNOS activity and release of nitric oxide via a non-genomic effect that is due to an increase in intracellular calcium [37]. Data also suggest that there is a plasma membrane-associated, G-protein coupled estrogen receptor (GPR30 or GPER) [41]. However, the specificity of this receptor is controversial since GPR30 also mediates rapid aldosterone-mediated effects on the vasculature $[32,33,72]$. Androgens also produce genomic effects via androgen response elements (AREs) in genes, but cause acute vasodilation by a non-genomic mechanism that involves activation of calcium activated potassium channels $[73,74]$. Future studies are necessary to completely understand the genomic and non-genomic effects of sex steroids and the mechanisms responsible for modulating cardiovascular function including whether the chromosomal constitution of the cell modulates responses to steroids via transcription factors, differential expression of protein chaperones, methylation of DNA, and so on $[32,33,72]$.

Experimental animals Several mammals are used in studies of cardiovascular disease. General considerations for the selection of the appropriate species include cost, size, housing requirements, diurnal activity cycle, diet requirements (soy or plant based influencing consumption of phytoestrogen) [75], lifespan, frequency of estrous cycle in females, ability to perform genetic manipulations, ability to investigate developmental and/ or environmental components of disease modulation [76]. Stress imposed by disruption of sleep/wake cycles, patterns of social interaction (or degree of social isolation), or handling may influence some parameters (for example, corticosteroids and catecholamines) that interact with pathways activated by the sex-steroid hormones $[77,78]$.

Of the small mammals, rats and mice are used most often to model cardiovascular disease because of their short life span, short estrous cycle and gestation, modest cost of housing, and the ability to perform genetic manipulation in them. Both the strain and sex of the animals are known to influence expression of cardiovascular pathologies $[79,80]$.

Transgenic mice (and some transgenic rats) that contain estrogen and androgen receptor knockouts are commercially available for study. Although preliminary, use of these animals to study the onset and progression of vascular disease has shown that the number of vascular progenitor cells found in bone marrow and blood is decreased in estrogen receptor knockout (ERKO) mice compared to wild type controls. These transgenic animals are especially valuable to study the role of sex steroids and their receptors in cardiovascular disease. While the global ERKO mice are viable and fairly healthy, global androgen receptor knockouts (ARKO) have serious developmental problems [81]. For example, the global ARKO exhibit neutropenia, osteopenia, low levels of serum testosterone, arrested spermatogenesis, and females have a reduced number of pups compared to wild type mice [81]. Therefore, especially for androgen receptor, specific tissue-directed androgen receptor knockouts, using Cre-loxP methods, are preferred [82-85]. Cre-loxP technology allows for knockout or expression of a gene of interest in a specific tissue [86]. Briefly, the site-specific recombinase Cre (cyclization recombination) from the bacteriophage $\mathrm{P} 1$ is used to induce recombination between two $34 \mathrm{bp}$ recognition sites (loxP $=$ 'locus of crossing over in P1') inserted into the genome. These loxP sites contain two $13 \mathrm{bp}$ inverted repeats surrounding an $8 \mathrm{bp}$ core sequence that provides directionality. Thus, two transgenic mouse strains are necessary to develop a cell-specific knockout: one strain that has the Cre recombinase expressed under the control of a cell specific promoter, and one that contains the gene of interest (or a critical exon of it) that is flanked by two loxp sites (termed 'floxed'). Following one round of crossbreeding, double transgenic pups containing both the floxed transgene and the Cre transgene are selected by genotyping. In a second round of breeding the double heterozygotes are either inbred or bred to the floxed mouse line. In the F2 generation, heterozygotes for the floxed allele and the Cre transgene are selected since the floxed gene/exon will be excised selectively in the cell types that express Cre recombinase (taken from review in [86]). For the androgen receptor, there have been several Cre/loxP mice developed for reproductive tissues, as well as adipose tissues, skeletal muscle, bone, $\mathrm{T}$ cells and $\mathrm{B}$ cells, liver and skin, to 
name a few [82]. The use of cell-specific knockouts of AR thus allows the investigator to specifically study the role of AR in their tissue/cell of choice while minimizing the effects of global changes that would complicate the study and perhaps make interpretation ambiguous. It should be kept in mind that the gene for the androgen receptor resides on the $\mathrm{X}$ chromosome. Thus, studies androgen actions in females are complicated by $\mathrm{X}$ inactivation which results in mosaic expression of any polymorphisms that reside in this gene or others which have the potential to affect cardiovascular function in females.

One caveat about the use of mice, transgenic or otherwise, is that uncertainties still exist regarding the degree to which cardiovascular phenomena, especially the pathobiology of atherosclerosis in these rodents, can be translated to human beings (see review in [87]). However, Taylor and colleagues $[65,66,88]$ have shown in apoE-/- mice and preliminarily in ERKO mice: (1) the onset and progression of atherosclerosis differs in male and female animals with the onset of disease occurring earlier in males and catching up with aging in females, similar to that in humans; (2) that the composition of the bone marrow in male and female animals differs and changes over time with aging consisting with the onset and progression of disease; (3) that the use of bone marrow mononuclear cells from females is sufficient to decrease atherosclerotic plaque in males but that the converse is not true; and (4) that the number of circulating cytokines differs based on sex and degree of disease with proinflammatory cytokines being higher in the circulations of males than in females.

Based on a spontaneous deletion of the SRY gene from the Y chromosome, Arnold and colleagues have developed transgenic animals for evaluating whether a phenotype follows gonadal sex or sex chromosome complement [89]. For example, these investigators developed transgenic animals to 'knock-in' the SRY gene on an autosome of XX animals to provide mice that have testes but XX chromosomes; alternatively, with the spontaneous deletion of the SRY gene from the Y chromosome, mice have ovaries but XY chromosomes. This allows the investigator to determine if a sex difference in phenotype correlates with the type of sex chromosomes (XX or XY) or with gonadal sex of the animal. Using these intact and gonadectomized animals, investigators can separate the contribution of sex steroids from sex chromosomes (the interaction of sex and sex hormones, that is, sex specific hormone action) in mediating sex differences in cardiovascular function and dysfunction.

In addition to transgenic animals, inbred and congenic strains of rats have been used extensively to study mechanisms responsible for sex differences in cardiovascular disease etiology. For example, Dahl salt sensitive rats exhibit hypertension with aging or more rapidly with a high salt diet [90]. High salt diet-mediated hypertension is exacerbated in males and ovariectomized females and attenuated in castrated males and intact females [91,92]. Spontaneously hypertensive rats (SHR) also exhibit sex differences in blood pressure control, with males exhibiting higher blood pressures than females [93]. Sex differences in the pressor response to angiotensin II have also been documented in mice and rats $[94,95]$.

With regard to rat models that mimic menopause, both SHR and Dahl salt sensitive rats have been used. Both strains of rats exhibit naturally increasing blood pressure when they stop estrous cycling, and have been used to study the mechanisms responsible for postmenopausal hypertension. However, in female rats after cessation of estrous cycling, estradiol levels do not fall as low as in women following menopause which is a common criticism of using rats as a model of menopause. To address this problem, investigators have used 4-vinylcyclohexene diepoxide (VCD), a chemical toxin that causes ovarian failure by targeting pre-antral follicles [96-99]. VCD can be used in rats and mice and allows for studies to be performed during a perimenopausal period $[96,100]$. Treatment of animals with VCD causes a follicular depleted state and a cessation in the production of female ovarian hormones within approximately 50 to 75 days after injection, with full cessation of estrogen production and obsolescence of the follicles by 129 days [97]. The advantages of this model are twofold. First, the rodents undergo a sustained period with no estrogen production. Second, VCD can be given in a young adult animal to simulate early ovarian failure [101]. Since the VCD ovary produces androgens just as do ovaries of postmenopausal women, perhaps this best models ovarian failure in women [102-106]. The investigator should keep in mind that studies in women with early ovarian failure (19 to 39 years of age) showed that they responded to transdermal estradiol with reductions in blood pressure, angiotensin II and creatinine [107], whereas in women who go through natural menopause (average age 51 years), the effects of estradiol are not as clear which was evident by the results of the Women's Health Initiative [108]. Thus, chemical menopause may be a better option to examine interactions of aging with estrogen depletion rather than the loss of all ovarian hormones as would result from ovariectomy.

There is a growing literature that considers sex differences in mouse strains and cardiovascular disease, sexspecific differences in the impact of particular bone marrow, blood, cardiac and vascular progenitors cells $[65,66]$ and sex-specific influence of particular gene effects $[87,109,110]$. In this light, many of the strategies used by geneticists to identify and characterize specific 
gene effects on cardiovascular disease-related phenotypes can easily accommodate tests of hypotheses surrounding the sex specificity of those gene effects, as will be discussed in the section on 'Identifying genes that exhibit sex-specific or sex-interaction effects' below.

Rabbits historically have been used in studies of autonomic and pharmacological regulation of vascular tone and vascular remodeling associated with atherosclerosis, ischemia reperfusion and stroke [111-122]. The Watanabe breed develops spontaneous atherosclerosis $[123,124]$, but other breeds develop atheromatous lesions in conduit arteries after feeding with high cholesterol diets $[112,113,125,126]$. Sex differences for some vascular functions and castration with hormone replacement indicate that both sex and hormones modulate these effects [127-129]. Rabbits also express the same myocardial contractile protein isoforms as humans (for example, $\beta$ versus $\alpha$ myosin heavy chain in the adult ventricle) and have a myocardial blood reserve that more closely resembles humans [130] more so than that of rats or dogs [131]. Based on these similarities to humans, rabbits have also been used to evaluate acute myocardial infarction therapies [132-134].

Rabbits and rodents are coprophagic thus influencing dietary sources of protein [135]. It is unclear how this activity influences immunological responses in these species related to nitric oxide synthase Il (iNOS) or other isoforms of NOS that might be regulated by estrogen and are associated with inflammatory responses proposed as a stimulus for endothelial dysfunction and vascular disease [136-139].

Larger mammals, such as cattle, sheep, dogs, pigs and primates, offer the advantage of scale for testing devices and procedures to be developed in humans (for example, [140]) but are disadvantaged by availability, cost, and special requirements for handling and husbandry. While some large animals are available from commercial breeders, others are not, and it may be economical for some tissues to be obtained from abattoirs (cattle, pigs). However, limitations on sources may make it difficult to determine the sex and or hormonal status of the tissue donor. Commercially available animals may be castrated at birth, which affects hormonally mediated developmental processes, or may be sexually immature at the time of study making extrapolation of data to adult animals problematic. Retired breeder females have been used for studies of aging, but it is unclear if cardiovascular function(s) of multiparous animals are the same or different from age-matched nulliparous females or aged matched males. Reckelhoff and colleagues reported that renal function was decreased in Sprague Dawley female rats who had had six to seven pregnancies and lactations compared to virgin females [141], whereas Baylis and colleagues reported that renal function and blood pressure were not affected by three pregnancies and lactations in spontaneously hypertensive rats [142]. Retired breeder rabbits have been used for models of cell-based treatment for acute myocardial infarction and seem to be a reasonable model for human disease [132-134]. Thus, studies in retired breeders may more closely mimic the cardiovascular systems of most women than do virgin female animals.

Historically, dogs were the experimental animal of choice for investigating mechanisms of cardiac regulation and autonomic control of the vasculature, renal function, models of disease, development of imaging modalities, testing novel therapeutics, basic pharmacology of endothelial and smooth muscle function and aging [143-153]. Depending on the source of the animals, however, it may not always be possible to obtain information on age or reproductive history. While studies of ovariectomized and hormone replaced female dogs have been performed [152,154], studies in castrated male dogs are not reported in cardiovascular literature.

Swine smaller than $100 \mathrm{~kg}$ used in research are usually sexually immature, with the exception of Yucatan miniswine. Depending on the supplier, males may be castrated at birth, so designation of 'male' with a weight of less than $100 \mathrm{~kg}$ may not represent results comparable to sexually mature animals [155-157]. Alternatively, sexually immature females (about 3 months of age) are used to maintain manageable sizes. The level of maturity or hormonal status for these animals is often not reported in methods sections of scientific papers. Ossabaw miniature swine (Sus scrofa) have a 'thrifty genotype' that when fed a high caloric diet enables them to store fat in order to survive seasonal food shortages. The phenotype of these female animals including central obesity, insulin resistance, impaired glucose tolerance, dyslipidemia and hypertension, are characteristics comparable to those used to define metabolic syndrome in humans. The atherosclerotic lesions in coronary arteries of the diabetic swine are similar to those found in humans and the size of the arteries are acceptable for testing coronary interventions such as stenting [158-160], thus providing an appropriate experimental animal to evaluate basic mechanisms of type II diabetes and treatment strategies which might be more easily be translated to human disease/treatment [159].

Non-human primates have been used extensively to study the natural history of atherosclerosis in relation to sex differences (See $[77,161])$. Rhesus and cynomolgus monkeys (Macaca mulatta, Macaca fascicularis, respectively) are particularly useful when fed diets that elevate blood lipids and the animals develop lesions consistent in morphological characteristics and location with those in humans with hyperlipidemia [78]. For example, atherosclerosis develops first in the aorta and proximal 
portions of the main branch coronary arteries and later in the common and internal carotid arteries. At risk animals (that is, those consuming an atherogenic diet) experience myocardial infarction at a rate similar to that of their human counterparts [162]. Finally, the macaques and other Old World anthropoid primates uniquely resemble women in reproductive function, as exemplified by similarities in ovarian hormone profiles, the presence of a menstrual cycle, and the occurrence of menopause [163].

An extensive series of studies, most conducted using socially housed female and male cynomolgus monkeys fed a diet relatively high in fat and cholesterol (designed to mimic typical consumption in industrialized countries) has resulted in seminal observations affecting design of future investigations with translation to human studies and evaluation of cardiovascular risk. The points below delineate these key findings.

(1) Females typically develop less atherosclerosis than males (see $[77,164]$ ). However, among socially housed monkeys this female 'protection' extends only to animals dominant within their social group; subordinate females exhibit a 'precocious acceleration' of atherosclerosis and are equivalent to males in coronary artery atherosclerosis extent.

(2) The precocious atherosclerosis that characterizes subordinate females likely results from a subclinical stress-induced, reversible ovarian impairment that resembles functional hypothalamic amenorrhea/anovulation (FHA) observed in women $[165,166]$. This hypothesis is supported by the observation that ovariectomy eliminates the protection of dominant females, rendering them equivalent to subordinate females and males in atherosclerosis extent $[165,167]$. Treatment of subordinate animals with exogenous estrogen (oral contraceptives) inhibits the development of atherosclerosis $[168,169]$.

(3) The trajectory of premenopausal atherosclerosis predicts postmenopausal atherosclerosis extent. In a two-part study reproductively intact monkeys consumed an atherogenic diet for 2 years, half were also treated with an oral contraceptive [168]; all animals were ovariectomized and continued to consume an atherogenic diet for 3 more years. Atherosclerosis extent at ovariectomy (as determined in an iliac artery biopsy) predicted the amount of atherosclerosis present at the end of the study $[169,170]$, irrespective of postmenopausal interventions.

(4) The extensive atherosclerosis that accompanies ovariectomy can be substantially inhibited by treatment with exogenous estrogens (for example, conjugated equine estrogens or $17 \beta$ estradiol), only if treatment begins immediately following ovariectomy in animals initially free of atherosclerosis [171]; treatment of animals with pre-existing atherosclerosis is ineffective in proportion to the amount of lesion present [172,173].

The primary lesson from studies of female monkeys is that stress-induced premenopausal ovarian dysfunction, a common and subclinical condition, puts affected individuals on accelerated trajectory for atherosclerosis. Furthermore, the trajectory of atherosclerosis established in the premenopausal years appears to determine postmenopausal lesion extent, underscoring the importance of early events in the development of the postmenopausal disease burden.

Although studies in non-human primates have provided data for several decades of research and form the basis of studies in humans, the cost and difficulty of working with these animals make them prohibitive for many investigators in the future. In this regard, the US National Institutes of Health (NIH)-sponsored National Primate Research Center program and specialized colony resources (the Animal and Biological Materials Resources program) may provide investigators with access to animals and expertise to conduct studies with monkeys. Access to these resources is described at the website of the Division of Comparative Medicine (currently part of the National Center for Research Resources but soon to be moved into the Office of the NIH Director).

\section{Establishing hormonal status in experimental animals}

If hormones are implicated in the pathogenesis of cardiovascular disease, then it is incumbent upon those studying cardiovascular disease in experimental animals to understand how to quantify gonadal function. In experimental animals, frequency of estrus in females is species dependent: polyestrus with several cycles throughout the year (mice, rats, pigs, primates including humans), seasonal polyestrus with several cycles occurring at particular times of the year (sheep, hamsters) or diestrus with two cycles per year (dogs).

In order for female rats and mice to exhibit estrous cycling, they must be maintained in a $12 \mathrm{~h}$ light/dark cycle in a temperature-controlled room free of vibrations or external noise. Rats and mice of both sexes can be fertile as early as 5 to 6 weeks of age ( $37.3 \pm 0.7$ days [174]), although the age at puberty can vary in female mice depending on whether males are present. In rats and mice, the estrous cycle in adult females is 3 to 5 days, and gestation is 21 to 22 days. Animals caged together will often cycle together. In addition, rats and mice cease estrus cycling with aging (similar to menopause), but the age may vary with strain [175]. For example, Sprague Dawley rats stop estrous cycling at 16 to 18 months of age. However, female hypertensive rats, such as the spontaneously hypertensive rat and the Dahl salt sensitive rat maintained on a low salt diet $(0.3 \%$ $\mathrm{NaCl}$ ), both stop estrous cycling between 10 to 12 
months of age $[91,176]$. At the beginning of estrous cycle cessation, vaginal smears show constant diestrus cells that lasts 1 to 3 months. Rats eventually cycle into constant estrus. Mice are similar and stop estrous cycling at 11 to 16 months of age depending on strain [175].

A common way to determine the progression through the cycle is by vaginal cytology. This method in mice is described in detail elsewhere [19] and is similar for rats. Briefly, wetted cotton swabs are placed into the vagina of the rat or mouse and twirled. Swabs containing accumulated cells are rolled onto dry glass slides and the slides are allowed to dry. The dry slides are stained with $0.1 \%$ toluidine blue, allowed to dry, and cell populations are viewed with a light microscope to observe cell morphology and populations. Alternatively, for vaginal lavage, $50 \mu \mathrm{l}$ of deionized water is placed into the vaginal vault with a plastic pipette taking care not to stimulate the cervix [177] that can result in pseudopregnancy. (Just as in pregnant animals, pseudopregnant animals develop physiological changes, including weight gain, increases in glomerular filtration rate, renal plasma flow, and cardiac output, until days 11 to 13 when they revert back to the physiology of the non-pregnant state $[178,179]$.) The pseudopregnant model is useful for studies of early pregnancy without the presence of the fetoplacental unit, and development of pseudopregnancy in rats and mice can also be accomplished by placing the females with vasectomized males.

On vaginal cell morphology, diestrus is characterized mainly by polymorphonuclear neutrophils (PMNs). Proestrus is characterized by a preponderance of larger nucleated epithelial cells. Estrus is characterized by irregularly shaped, cornified cells that contain pyknotic or no visible nuclei. Metaestrus is characterized by a combination of cornified cells and PMNs [19]. 17 $\beta$-estradiol and progesterone levels are highest during proestrus and lowest during estrus [180-182]. To achieve pregnancy, female rats and mice are placed with a male preferably during diestrus. The presence of sperm on the vaginal smear or presence of a sperm plug is termed 'day 1 of pregnancy'.

Staging ovarian cycle in female rabbits is difficult because rabbits are in a prolonged state of proestrus. Vaginal probing initiates a surge in gonadotropins that induces ovulation making them similar to other species such as mink, ferrets, domestic cats, voles, and camels in being characterized as 'reflex ovulators'. In contrast, the surge in gonadotropins resulting in ovulation originates internally in rats, pigs, sheep, cows, non-human primates, and women, leading to their designation as 'spontaneous ovulators' [183]. Ovarian cycles in swine are monthly and females housed together will synchronize their cycles.
Staging reproductive cycle stages may also be discerned by visual (vulvar swelling or discharge), behavioral signs, vaginal impedance, steroid levels in urine or serum, or reproductive tract histology depending on species. It is difficult to identify estrus in female pigs by changes in external genitalia and estrus is often staged by behavioral postural changes in the presence of a male. Female swine are sensitive to stress, such as changes in housing, which can disrupt cyclicity. As discussed, anthropoid primates, including Old World monkeys and women, appear especially sensitive to the suppressive effects of negative social interaction or environmental circumstances $[163,165,184]$.

Gonadal function is rarely quantified in studies using male animals except with identification of reproductive maturity and orchiectomy. In humans, men exhibit declines in testosterone and sperm production when stressed by metabolic/nutritional/energetic deficiencies and women exhibit declines in ovarian function and fertility when stressed, but what is stressful to women differs from what is stressful to men. Comparable studies in most experimental animals are lacking. In nonhuman primates, suppressed ovarian function secondary to social stress is common and is clearly associated with precocious acceleration of cardiovascular disease $[77,161,184]$. These effects of androgens have not been systematically assessed on cardiovascular disease of male monkeys, although atherosclerosis is exacerbated in ovariectomized females treated with either androstenedione or testosterone [185].

\section{Delivery of hormones to castrated animals}

Timing of castration/gonadectomy (that is, removing the gonads shortly after birth prior to sexual development or after puberty) in animals may be critical in the development or progression of cardiovascular disease. Caution should be exercised in the choice of hormones used to treat (replace) in a particular study. For example, both testosterone and $17 \beta$-estradiol are metabolized to biologically active substances. Progesterone at high concentrations binds to glucocorticoid receptors and some synthetic progestogens may have greater affinity for these receptors than others (see section 'What are sex steroid hormones?' above).

Sex steroids are typically given to experimental animals either by intramuscular injection or by subcutaneous implantation of time-release pellets. For intramuscular injections, an oil vehicle, such as castor oil or sesame oil is used. The disadvantage to this method is that daily injections are required for chronic studies. For studies in which sustained and consistent levels of steroids are the objective, commercially available pellets containing estradiol, progesterone, testosterone, dihydrotestosterone, or placebo, are implanted subcutaneously on the back of the animals. Pellets of 
different release times are available to achieve the plasma levels desired. Alternatively, sex steroids can be packed into medical grade silastic tubing, capped with silastic glue and implanted subcutaneously on the back of the animal [186]. The delivery dose depends on the length of the tube and the amount of steroid in the tube. These implants may be equilibrated by incubation in physiological saline for 24 hours to reduce the variability in initial release. With either of these subcutaneous delivery methods, plasma levels of hormones should be monitored for validation.

To mimic estrous cyclicity similar to normal rats and mice, ovariectomized animals can be injected with estradiol and progesterone, as described by Kramer and Bellinger [182]. These investigators used osmotic minipumps to deliver low doses of $17 \beta$-estradiol benzoate in ovariectomized female rats to mimic levels during the diestrus and estrus phases. Rats then received additional $17 \beta$-estradiol benzoate injections every 5 days to mimic proestrus increases. The investigators performed vaginal smears twice daily and found that the estrous cycles in the treated rats mimicked the cycles in intact females (for details on vaginal cytology, see [19]).

Oral preparations of sex steroids can be used but care is needed to assure that the animal consumes the steroid. Non-human primates can be easily trained to take measured amounts of oral formulations, however hormones can also be delivered to these species in the diet, for example, [169,187]. Final blood concentrations reached with given preparations (concentration) depends on steroid metabolism related to first pass metabolism in the liver.

\section{Measurement of sex steroids}

It is usually possible to obtain a blood sample for the measurement of sex steroids in experimental animals. The gold standard for measurement of sex steroids such as testosterone is liquid chromatography linked with mass spectroscopy [188]. This method removes any possibility of cross identity of antibodies with similar steroids, such as testosterone with $5 \alpha$-dihydrotestosterone or estradiol, in ELISAs or radioimmunoassays (RIAs). This method may not be cost effective or feasible in all research or clinical environments.

Various ELISA or RIA kits for sex steroid measurement are commercially available. Estradiol and dihydrotestosterone are the most difficult to measure and often require extraction of plasma or serum to obtain consistent results. RIA kits may be difficult to use since the isotope used for many kits is radioactive iodine-125 and requires special precaution for use, radioactivity institutional permission, and disposal of gamma radioactivity.

One potential way to mitigate the problems associated with determination of circulating hormones is to assess such hormone concentrations in conjunction with measurement of menstrual cyclicity (as determined by vaginal swabbing). It has been observed in monkeys, for example, that abnormalities in ovarian hormone profiles are mirrored by irregularity in menstrual cyclicity [184].

One precautionary note is that measurement of hormones in the circulation may not be reflective of the active product at the tissue or cellular level because of the local metabolism of the sex steroids. Many organs outside of the reproductive organs contain receptors for sex steroids, and have the capacity to synthesize these steroids due to the presence of cytochrome P450 enzymes (see section 'What are sex steroid hormones?' above). For example, the kidney can produce sex steroids and androgen receptor and ER $\alpha$ are present in renal vascular and tubular cells [42]. However, the role that extragonadal steroid synthesis plays in mediating cardiovascular alterations in specific organs is not clear and requires further investigation.

The other compartment of interest may be the cerebrospinal fluid (CSF). Circulating levels and CSF levels of sex steroids have rarely been simultaneously quantified. In the systemic circulation buffering mechanisms keep hormonal excursions within a given range; these mechanisms do not seem to operate in the CSF. Hormones, especially cortisol, in CSF are not bound to any significant degree, thus, CSF hormone levels are 'free' and therefore bioactive [189]. These differences might be important in etiology of cardiovascular disease as much as cardiovascular regulation including that driven by stress and baroeceptors and chemoreceptors related to hypertension depends on neural mechanisms.

\section{Identifying genes that exhibit sex-specific or sex- interaction effects}

An approach to the identification of genes that influence cardiovascular disease and related phenotypes involves genotyping a large number of individual progeny from a cross involving inbred (or in some circumstances outbred) strains of mice, rats, flies, or another model species, and using statistical tests to determine if there are loci that harbor genotypes or genetic variants that cosegregate with the phenotype of interest. This basic approach, often referred to as 'quantitative trait locus' (QTL) mapping has been pursued for years, with a number of published reviews describing relevant strategies for implementing the approach, successes with the approach as well as issues with its various formulations $[190,191]$. QTL mapping studies rarely, if ever, lead to the actual identification of phenotypically relevant causative genetic variants, but rather lead to the identification of a genomic region that is likely harboring a phenotypically relevant variant. This fact has important implications for QTL mapping studies seeking to identify genetic variants that contribute to sex-specific 
cardiovascular phenotypes, since, if evidence for cosegregation between a genetic variant and a sex-limited to sex-specific effect was found in QTL mapping study, work would still be required to identify the actual causal variant(s) and understand its molecular or gross physiologic impact or function.

Unfortunately, few QTL mapping studies have identified, or even attempted to implicate sex-dependent gene or genetic variant effects. However, QTL mapping strategies could easily accommodate testing hypotheses surrounding sex-dependent penetrance or sex $\times$ gene interaction effects, as described below. In addition, phenotypic comparisons across inbred (or outbred) strains are often pursued in anticipation of a QTL mapping study and could also easily accommodate sex-specific analyses. Results of such strain comparisons could motivate the search of genetic variants that have sex-limited or sex-dependent effects.

There is a rich established literature base describing the use of many different model species in genetic analyses (including QTL mapping studies) of cardiovascular disease, such as fruit flies [192,193] and baboons $[194,195]$. However, studies involving mice and rats have been pursued more frequently in strain comparison and QTL mapping studies. This prominence is more than likely due to the availability of many inbred mouse and rat strains that have been characterized for differences in cardiovascular phenotype profiles. The strain comparison and QTL mapping strategies and resources described below, all involving different mouse or rat strains, have been pursued by geneticists to identify genes contributing to cardiovascular disease related phenotypes that exhibit sex-specific effects.

\section{Basic strain difference analysis}

Many studies have investigated differences in cardiovascular disease-related phenotypes between different mouse and rat strains (see, for example, [196,197]). Since many mouse and rat strains have been inbred to homozygosity and have been reared in the same laboratory conditions, phenotypic differences between the resulting (clone-like) animals from different strains can be attributed to DNA sequence differences between them. Analyses of strain differences can easily accommodate sex differences if male and female animals with phenotype information are available. As simple in orientation as such studies may be, however, they have not been pursued with great frequency, probably because of the number of individual mice or rats one might need to detect realistic yet statistically significant strain $\times$ sex interaction effects that could be prohibitive. As an example of a strain comparison study involving cardiovascular phenotypes, Nadeau and colleagues contrasted homocysteine levels and related phenotypes across multiple mouse strains [198] and found a number of differences in a number of additional cardiovascular disease-related phenotypes obtained via elaborate phenotyping protocols [199]. The assessment of strain and sex differences between different mouse strains is greatly facilitated through searchable online strain phenotypic characteristic databases and simple push-button statistical analysis tools, such as those provided in the Mouse Phenome Database [200]http://www.jax.org/phenome.

\section{In silico genetic analysis}

The genomes of many mouse and rat strains have been sequenced, and analyses of these genomes have revealed substantial differences between them [201-203]. By contrasting and correlating the genetic differences between strains with phenotypic differences between those strains, one could potentially identify genetic variants that are associated with those phenotypes. The use of extant strain genetic and phenotypic data in this context is referred to as 'in silico' QTL mapping since it involves summary and statistical analysis of existing data and not the generation of new data [204]. Statistical analyses involving in silico QTL mapping studies can easily accommodate hypothesis tests concerning sex-specific genetic effects, and can be greatly enhanced through the use of strain phenotype databases (for example, the Mouse Genome Database [205]) and online statistical analysis tools, such as those assembled within the Mouse Phenotype Association Database (MPAD; http:// mouse.cs.ucla.edu/perl/mpad/pcont.pl).

\section{Individual crosses and QTL mapping}

As noted, the most widely used approach for identifying genetic factors that influence a particular phenotype involving model organisms is QTL mapping, in which crosses between different strains are exploited that differ phenotypically. QTL mapping strategies can easily accommodate hypotheses about sex-specificity of genetic variants, assuming a sufficient number of male and female progeny are available, through the use of appropriate statistical models that accommodate interaction terms, such as regression models where a phenotype is taken as a dependent variable and genotype is an independent or predictor variable. The inclusion of sex as an additional independent variable as well as a genetic variant $\times$ sex interaction term can be used to test hypothesis about sex specific genetic variant effects. Jacob and colleagues explored the sex-specific genetic effects on hypertension-related traits using very sophisticated pharmacologic and phenotyping protocols in crosses involving inbred rat strains [206,207]. Chromosome substitution strains, in which chromosomes from a strain with a particular phenotype are introgressed through breeding programs into a strain without that phenotype, have been used to identify the chromosomes carrying sex-specific genetic factors for cardiovascular disease-related traits in rats [208]. Nadeau and 
colleagues have pursued similar, very elegant, studies with mouse strains [209,210].

A number of other researchers have pursued QTL mapping studies that have explored sex-specific or sex $x$ genetic variant interaction effects, but not necessarily for specific cardiovascular disease-related phenotypes but cardiovascular related risk factors. For example, sex $x$ genetic variant effects influence fat mass and body size $[211,212]$ in addition to the prevalence of sex-specific variant effects on a wide variety of complex phenotypic endpoints [213]. Expression levels of particular genes have been evaluated as a way of understanding the molecular physiologic impact of genetic variants that may ultimately impact phenotypic expression [214]. Other considerations include how to characterize sex specific genetic networks that impact phenotypic expression using QTL mapping studies [60,215]. In addition, studies of diet-induced bone loss using QTL mapping strategies have found evidence for sex-specific variant effects [216].

\section{The large-scale multiple mouse strain Collaborative Cross}

Since crosses involving two strains can only exploit the DNA sequence variation within those two strains and hence are limited with respect to the amount and possible interactions among many different sequence variants, the 'Collaborative Cross' (CC) was initiated by a number of prominent mouse geneticists $[217,218]$. The $\mathrm{CC}$ was designed to consider multiway crosses of eight founder mouse strains, resulting in greater genetically determined phenotypic diversity among the progeny than a typically two-way cross. In addition, based on calculations of the diversity and progeny size generated by the cross, the CC could have an ability to map QTLs at an approximately 1 megabase resolution, meaning that a causal variant might be very close to a marker associated with a trait if identified through the CC. The CC is considered a community resource and will be an ideal model system for the study of sex by gene interactions on cardiovascular disease and related phenotypes. A very recent study leveraging the $\mathrm{CC}$ for the study of genetic factors underlying energy balance traits showcases its potential [219].

\section{Statistical analysis}

Essential to advancing the science and developing treatments/approaches to reduce disparities in healthcare between women and men, the sex of the experimental material (cultured cells, animals, humans) must be reported. While this information was once routinely given in Methods sections of scientific papers, a recent survey of the basic science literature related to brain and behavior found that about $75 \%$ of published papers in areas of physiology and pharmacology related to brain research did not report the sex of the animals $[16,17,220]$ and only about $20 \%$ of papers published in cardiovascular journals with high impact factors reported the sex of cells studied in culture [18]. Since sex is a dichotomous variable, data should be analyzed by sex. This analysis is separate from incorporating sex in multivariate analysis of data. Negative or null data should be reported. Knowledge is to be gained from understanding in which systems/pathways or responses sex matters and to understand and compare differences between sexes for conditions in which one sex is most affected or most protected [221].

\section{Conclusions}

The following conclusions can be reached (see also Table 1). (1) Sex is a variable in defining mechanisms responsible for cardiovascular structure and function in health and disease, and must be considered for all experimental designs and system choices (that is, cell culture, isolated tissues and whole animals, including genetically manipulated animals). (2) Phenotypes dictated by the sex chromosomes are modulated by sex steroid hormones; therefore, sex and hormonal status are critical in the design of experiments. (3) If differential experimental results occur in animals based purely on sex, much can be gained by studying the "most affected' as well as the 'most protected' sex. (4) Studies in animals need to account for hormonal/gonadal status in both males and females (that is, intact, gonadectomized, sexually immature, hormone replete or replaced), as well as reproductive history of females. (5) Experiments that utilize both female and male animals should be sufficiently powered to detect sex difference if they exist or if not to provide confidence in a null finding, which should be reported. Analysis by sex includes sex as a dichotomous variable as well as a covariate. (6) As numerous studies have identified differential responses between sexes in etiology, consequences and treatment of cardiovascular disease, the idea that studies of

Table 1 Considerations for design of studies of sex and cardiovascular structure and function in health and disease

\begin{tabular}{|c|c|}
\hline 1. Concepts of sex differences must be integrated into research design. & $\begin{array}{l}\text { 4. The hormonal and gonadal state must be considered along with } \\
\text { reproductive history in females. }\end{array}$ \\
\hline $\begin{array}{l}\text { 2. Phenotypes are dictated by sex chromosomes and modulated by sex } \\
\text { steroid hormones. }\end{array}$ & $\begin{array}{l}\text { 5. From a statistical standpoint, studies should be powered to detect sex } \\
\text { differences. }\end{array}$ \\
\hline $\begin{array}{l}\text { 3. A sex difference may be the simplest possible explanation for a } \\
\text { particular experimental outcome. }\end{array}$ & $\begin{array}{l}\text { 6. Extrapolation of experimental outcomes from one sex to the other is } \\
\text { invalid. }\end{array}$ \\
\hline
\end{tabular}


fundamental mechanisms of cardiovascular physiology and disease can be discerned by the study of one sex and extrapolated to the other is scientifically invalid.

\section{Author details}

'Departments of Surgery, Physiology and Biomedical Engineering, Mayo Clinic, 200 First Street SW, Rochester, MN, 55905, USA. ${ }^{2}$ Department of Pathology (Comparative Medicine), Wake Forest School of Medicine, Winston-Salem, NC, USA. ${ }^{3}$ The Scripps Research Institute and The Scripps Translational Science Institute, La Jolla, CA, USA. ${ }^{4}$ Department of Medicine, Johns Hopkins University, Baltimore, MD, USA. ${ }^{5}$ Department of Obstetrics and Gynecology, Wake Forest University, Winston-Salem, NC, USA. ${ }^{6}$ Department of Medicine, Division of Cardiology, Emory University School of Medicine, Atlanta, GA, USA. 'Emory Clinical Cardiovascular Research Institute, Emory University School of Medicine, Atlanta, GA, USA. ${ }^{8}$ Department of Physiology, Georgia Health Sciences University, Augusta, GA, USA. '95cience Department, Society for Women's Health Research, Washington, DC, USA. ${ }^{10}$ St Joseph's Healthcare, Hamilton, Ontario, Canada. ${ }^{11}$ Department of Integrative Biology and Physiology, Center for Cardiovascular Repair, University of Minnesota, Minneapolis, MN, USA. ${ }^{12}$ Women's Heart Center, Cedars-Sinai Heart Institute, Los Angeles, CA, USA. ${ }^{13}$ Women's Health Research Center and Department of Physiology and Biophysics University of Mississippi Medical Center, Jackson, MS, USA.

\section{Authors' contributions}

This paper represents a collaborative project of the ISIS Cardiovascular Network with each author providing expertise in her/his specialty such that the information is integrated throughout the entire work. VMM developed the conceptual framework, developed sections related to definitions, experimental animals, steroid signaling, impact and final editing; JRK provided expertise for overall conceptual framework, sections related to non-human primates, and steroid signaling; NJS provided sections related to genomics and experimental design; $\mathrm{PO}$ provided expertise regarding overall conceptual design, translational impact of work, and editing; SLB provided expertise on sections related to translation, hormone definitions and signaling and non-human primates, NKW provided expertise for overall conceptual framework and editing; LJS provided conceptual expertise related to translational application; RCW provided expertise on conceptual design, methods for animals studies and cultured cells, methods for delivery of hormones, and impact; MM oversaw administrative aspects of the work and editing; MS provided expertise on conceptual framework, definition of terms, methods for measurement of steroids and editing; DAT provided expertise for conceptual framework, design aspects related to experiments using cultured cells and progenitor cells; CNB provided expertise for conceptual framework, translation to human studies, definitions and editing; JFR provided expertise on overall conceptual framework, definitions, experiments related to rodents, delivery and measurement of hormones and editing. All authors approved the final version.

\section{Competing interests}

This work was made possible by a grant to the Society for Women's Health Research (SWHR) ISIS Cardiovascular Network. SWHR is a national, non-profit organization headquartered in Washington, DC, USA. VMM served as President of the Organization for the Study of Sex Differences, an affiliate of SWHR, from 2010 to 2012.

Received: 21 July 2011 Accepted: 12 December 2011 Published: 12 December 2011

\section{References}

1. WRITING GROUP MEMBERS, Lloyd-Jones D, Adams RJ, Brown TM, Carnethon M, Dai S, De Simone G, Ferguson TB, Ford E, Furie K, Gillespie C, Go A, Greenlund K, Haase N, Hailpern S, Ho PM, Howard V, Kissela B, Kittner S, Lackland D, Lisabeth L, Marelli A, McDermott MM, Meigs J, Mozaffarian D, Mussolino M, Nichol G, Roger VL, Rosamond W, Sacco R, et al: Heart disease and stroke statistics - 2010 update: a report from the American Heart Association. Circulation 2010, 121:948-954.

2. Mosca L, Benjamin EJ, Berra K, Bezanson JL, Dolor RJ, Lloyd-Jones DM, Newby LK, Piña IL, Roger VL, Shaw LJ, Zhao D, Beckie TM, Bushnell C,
D'Armiento J, Kris-Etherton PM, Fang J, Ganiats TG, Gomes AS, Gracia CR, Haan CK, Jackson EA, Judelson DR, Kelepouris E, Lavie CJ, Moore A, Nussmeier NA, Ofili E, Oparil S, Ouyang P, Pinn WW, et al: EffectivenessBased Guidelines for the Prevention of Cardiovascular Disease in Women-2011 Update: A Guideline From the American Heart Association. Circulation 2011, 123:1243-1262.

3. Gregg EW, Gu Q, Cheng YJ, Naranayan KMV, Cowie CC: Mortality trends in men and women with diabetes, 1971 to 2000. Ann Intern Med 2007 147:149-155.

4. Reckelhoff JF, Fortepiani LA: Novel mechanisms responsible for postmenopausal hypertension. Hypertension 2004, 43:918-923.

5. Wizemann TM, Pardue ML: Exploring the Biological Contributions to Human Health: Does Sex Matter? Board on Health Sciences Policy Washington, DC, USA: Institute of Medicine; 2001.

6. Shaw $L$, Bairey Merz CN, Pepine CJ, Reis SE, Bittner V, Kelsey SF, Olson M, Johnson BD, Mankad S, Sharaf BL, Rogers WJ, Wessel TR, Arant CB, Pohost GM, Lerman A, Quyyumi AA, Sopko G, WISE Investigators: Insights From the NHLBI-Sponsored Women's Ischemia Syndrome Evaluation (WISE) Study: Part I: gender differences in traditional and novel risk factors, symptom evaluation, and gender-optimized diagnostic strategies. J Am Coll Cardiol 2006, 47:S4-S20.

7. Shaw LJ, Bugiardini R, Merz CN: Women and ischemic heart disease: evolving knowledge. J Am Coll Cardiol 2009, 54:1561-1575.

8. National Institutes of Health: NIH Policy and Guidelines on the inclusion of women and minorities as subjects in clinical research.[http://grants.nih. gov/grants/funding/women_min/guidelines_amended_10_2001.htm].

9. European Commission: Vademecum. Gender Mainstreaming in the 6th Framework Programme-Reference Guide for Scientific Officers/Project Officers.[ftp://ftp.cordis.europa.eu/pub/science-society/docs/ gendervademecum.pdf].

10. Caron J: Canadian Institutes of Health Research. Report on governmental health research policies promoting gender or sex differences sensitivity. [http://dsp-psd.pwgsc.gc.ca/collection_2008/cihr-irsc/MR21-103-2003E.pdf].

11. Geller SE, Koch A, Pellettieri B, Carnes M: Inclusion, analysis and reporting of sex and race/ethnicity in clinical trials: have we made progress? $J$ Women's Health 2011, 20:315-320.

12. Foulkes MA: After inclusion, information and inference: reporting on clinical trials results after 15 years of monitoring inclusion of women. $J$ Womens Health (Larchmt) 2011, 20:829-836.

13. Blauwet LA, Hayes SN, McManus D, Redberg RF, Walsh MN: Low rate of sex-specific result reporting in cardiovascular trials. Mayo Clin Proc 2007, 82:166-170.

14. Blauwet LA, Redberg RF: The role of sex-specific results reporting in cardiovascular disease. Cardiol Rev 2007, 15:275-278.

15. Melloni C, Berger JS, Wang TY, Gunes F, Stebbins A, Pieper KS, Dolor RJ, Douglas PS, Mark DB, Newby LK: Representation of women in randomized clinical trials of cardiovascular disease prevention. Circ Cardiovasc Qual Outcomes 2010, 3:135-142.

16. Wald C, Wu C: Of mice and women: the bias in animal models. Science 2010, 327:1571-1572

17. Beery AK, Zucker I: Sex bias in neuroscience and biomedical research. Neurosci Biobehav Rev 2011, 35:565-572.

18. Taylor KE, Vallejo-Giraldo C, Schaible NS, Zakeri R, Miller VM: Reporting of sex as a variable in cardiovascular studies using cultured cells. Biol Sex Differ 2011, 2:11.

19. Becker JB, Arnold AP, Berkley KJ, Blaustein JD, Eckel LA, Hampson E, Herman JP, Marts S, Sadee W, Steiner M, Taylor J, Young E: Strategies and methods for research on sex differences in brain and behavior. Endocrinology 2005, 146:1650-1673.

20. Gillies $G E$, McArthur S: Estrogen actions in the brain and the basis for differential action in men and women: a case for sex-specific medicines. Pharmaco Rev 2010, 62:155-198.

21. Fisher MR, Feuerstein G, Howells DW, Hurn PD, Kent TA, Savitz SI, Lo EH, STAIR Group: Update of the Stroke Therapy Academic Industry Roundtable Preclinical Recommendations. Stroke 2009, 40:2244-2249.

22. Greenspan JD, Craft RM, LeResche L, Arendt-Nielsen L, Berkley KJ, Fillingim RB, Gold MS, Holdcroft A, Lautenbacher S, Mayer EA, Mogil JS, Murphy AZ, Traub RJ, Consensus Working Group of the Sex, and Pain SIG of the IASP: Studying sex and gender differences in pain and analgesia: a consensus report. Pain 2007, 132:S26-S45.

23. Anonymous: Putting gender on the agenda. Nature 2010, 465:665. 
24. Kim AK, Tingen CM, Woodruff TK: Sex bias in trials and treatment must end. Nature 2010, 465:688-689.

25. Arain FA, Kuniyoshi FH, Abdalrhim AD, Miller VM: Sex/gender medicine: the biological basis for personalized care in cardiovascular medicine. Circ J 2009, 73:1774-1782.

26. Hamburg MA, Collins FS: The path to personalized medicine. N Engl J Med 2010, 363:301-304

27. Ginsburg GS, Willard HF: Genomic and personalized medicine: foundations and applications. Trans/ Res 2009, 154:277-287.

28. Bairey Merz CN, Mark S, Boyan BD, Jacobs AK, Shah PK, Shaw LJ, Taylor D, Marban E: Proceedings from the scientific symposium: sex differences in cardiovascular disease and implications for therapies. J Womens Health (Larchmt) 2010, 19:1059-1072.

29. Miller VM, Duckles SP: Vascular actions of estrogens: functional implications. Pharmacol Rev 2008, 60:210-241.

30. Liu PY, Death AK, Handelsman DJ: Androgens and cardiovascular disease. Endocr Rev 2003, 24:313-340.

31. Askew EB, Gampe RT Jr, Stanley TB, Faggart JL, Wilson EM: Modulation of androgen receptor activation function 2 by testosterone and dihydrotestosterone. J Biol Chem 2007, 282:25801-25816.

32. Feldman RD, Gros R: Rapid vascular effects of steroids - a question of balance? Can J Cardiol 2010, 26(Suppl A):22A-26A

33. Nilsson BO, Olde B, Leeb-Lundberg LM: G protein-coupled estrogen receptor 1 (GPER1)/GPR30: a new player in cardiovascular and metabolic estrogenic signaling. Br J Pharmacol 2011, 163:1131-1139.

34. Nilsson M, Dahlman-Wright K, Gustafsson JA: Nuclear receptors in disease: the oestrogen receptors. Essays Biochem 2004, 40:157-167.

35. Lokuge S, Frey BN, Foster JA, Soares CN, Steiner M: The rapid effects of estrogen: a mini-review. Behav Pharmacol 2010, 21:465-472.

36. Zhao C, Dahlman-Wright K, Gustafsson JA: Estrogen signaling via estrogen receptor $\beta$. J Biol Chem 2010, 285:39575-39579.

37. Duckles SP, Miller VM: Hormonal modulation of endothelial NO production. Pflugers Arch 2010, 459:841-851

38. Ware RS, Rockefeller University and Population Council NY, NY, USA: The pharmacological profile of progestins. Maturitas 2008, 61:151-157.

39. Attardi BJ, Page ST, Hild SA, Coss CC, Matsumoto AM: Mechanism of action of bolandiol (19-nortestosterone-3 $\beta, 17 \beta$-diol), a unique anabolic steroid with androgenic, estrogenic, and progestational activities. J Steroid Biochem Mol Biol 2010, 118:151-161

40. Wang H, Li J, Gao Y, Xu Y, Pan Y, Tsuji I, Sun ZJ, Li XM: Xeno-oestrogens and phyto-oestrogens are alternative ligands for the androgen receptor. Asian J Androl 2010, 12:535-547.

41. Prossnitz ER, Barton M: The G-protein-coupled estrogen receptor GPER in health and disease. Nat Rev Endocrinol 2011, 7:715-726.

42. Quinkler M, Bumke-Vogt C, Meyer B, Bahr V, Oelkers W, Diederich S: The human kidney is a progesterone-metabolizing and androgen-producing organ. J Clin Endocrinol Metab 2003, 88:2803-2809.

43. Mowa CN, Jesmin S, Miyauchi T: The penis: a new target and source of estrogen in male reproduction. Histol Histopathol 2006, 21:53-67.

44. Sowers MF, Wilson AL, Kardia SR, Chu J, Ferrell RE: Aromatase gene (CYP 19) polymorphisms and endogenous androgen concentrations in a multiracial/multiethnic, multisite study of women at midlife. Am J Med 2006, 119:523-530

45. Syed F, Khosla S: Mechanisms of sex steroid effects on bone. Biochem Biophys Res Commun 2005, 328:688-696.

46. Simpson ER, Davis SR: Minireview: aromatase and the regulation of estrogen biosynthesis - some new perspectives. Endocrinology 2001, 142:4589-4594

47. Miller VM: Estrogen metabolomics: a physiologists perspective. Hypertension 2010, 56:816-818.

48. Dubey RK, Tofovic SP, Jackson EK: Cardiovascular pharmacology of estradiol metabolites. J Pharmacol Exp Ther 2004, 308:403-409.

49. Berga SL: Systemic benefits of cyclic ovarian function. J Soc Gynecol Investig 2001, 8:S3-6.

50. Miller VM, Black DM, Brinton EA, Budoff MJ, Cedars MI, Hodis HN, Lobo RA, Manson JE, Merriam GR, Naftolin F, Santoro N, Taylor HS, Harman SM: Using basic science to design a clinical trial: baseline characteristics of women enrolled in the Kronos Early Estrogen Prevention Study (KEEPS). $J$ Cardiovasc Transl Res 2009, 2:228-239.

51. Manson JE, Hsia J, Johnson KC, Rossouw JE, Assaf AR, Lasser NL, Trevisan M, Black HR, Heckbert SR, Detrano R, Strickland OL, Wong ND, Crouse JR,
Stein E, Cushman M, Women's Health Initiative Investigators: Estrogen plus progestin and the risk of coronary heart disease. New Engl J Med 2003, 349:523-534.

52. Manson JE, Allison MA, Rossouw JE, Carr JJ, Langer RD, Hsia J, Kuller LH, Cochrane BB, Hunt JR, Ludlam SE, Pettinger MB, Gass M, Margolis KL, Nathan L, Ockene JK, Prentice RL, Robbins J, Stefanick ML, WHI and WHICACS Investigators: Estrogen therapy and coronary-artery calcification. $N$ Engl J Med 2007, 356:2591-2602.

53. Utian WH, Archer DF, Bachmann GA, Gallagher C, Grodstein F, Heiman JR, Henderson WW, Hodis HN, Karas RH, Lobo RA, Manson JE, Reid RL, Schmidt PJ, Stuenkel CA, North American Menopause Society: Estrogen and progestogen use in postmenopausal women: July 2008 position statement of The North American Menopause Society. Menopause 2008 15:584-603.

54. Santen RJ, Allred DC, Ardoin SP, Archer DF, Boyd N, Braunstein GD, Burger HG, Colditz GA, Davis SR, Gambacciani M, Gower BA, Henderson WW, Jarjour WN, Karas RH, Kleerekoper M, Lobo RA, Manson JE, Marsden J, Martin KA, Martin L, Pinkerton JV, Rubinow DR, Teede $H_{\text {, Thiboutot DM }}$ Utian WH, Endocrine Society: Postmenopausal Hormone Therapy: An Endocrine Society Scientific Statement. J Clin Endocrinol Metab 2010, 95(Suppl 1):S1-S66.

55. Ostrer H: Sex-based differences in gene transmission and gene expression. Lupus 1999, 8:365-369.

56. Avner $\mathrm{P}$, Heard $\mathrm{E}$ : X-chromosome inactivation: counting, choice and initiation. Nat Rev Genet 2001, 2:59-67.

57. McEwen BS: Invited review: Estrogens effects on the brain: multiple sites and molecular mechanisms. J Appl Physiol 2001, 91:2785-2801.

58. Pierce JP, Kievits J, Graustein B, Speth RC, ladecola C, Milner TA: Sex differences in the subcellular distribution of angiotensin type 1 receptors and NADPH oxidase subunits in the dendrites of $\mathrm{C} 1$ neurons in the rat rostral ventrolateral medulla. Neuroscience 2009, 163:329-338.

59. Isensee J, Witt H, Pregla R, Hetzer R, Regitz-Zagrosek V, Noppinger PR: Sexually dimorphic gene expression in the heart of mice and men. $J \mathrm{Mol}$ Med 2008, 86:61-74.

60. Yang $X$, Schadt EE, Wang S, Wang H, Arnold AP, Ingram-Drake L, Drake TA, Lusis AJ: Tissue-specific expression and regulation of sexually dimorphic genes in mice. Genome Res 2006, 16:995-1004.

61. Antoniucci D, Miller VM, Sieck GC, Fitzpatrick LA: Gender-related differences in proliferative responses of vascular smooth muscle cells to endothelin-1. Endothelium 2001, 8:137-145.

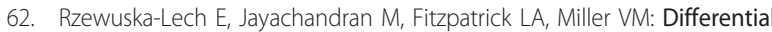
effects of $17 \beta$-estradiol and raloxifene on VSMC phenotype and expression of osteoblast-associated proteins. Am J Physiol Endocrinol Metab 2005, 289:E105-112.

63. Bai $Y$, Sun $T$, Ye $P$ : Age, gender and diabetic status are associated with effects of bone marrow cell therapy on recovery of left ventricular function after acute myocardial infarction: a systematic review and meta-analysis. Ageing Res Rev 2010, 9:418-423.

64. Martin EA, Tan SL, MacBride LR, Lavi S, Lerman LO, Lerman A: Sex differences in vascular and endothelial responses to acute mental stress. Clin Auton Res 2008, 18:339-345.

65. Zenovich AG, Taylor DA: Atherosclerosis as a disease of failed endogenous repair. Front Biosci 2008, 13:3621-3636.

66. Nelson WD, Zenovich AG, Ott HC, Stolen C, Caron GJ, PanoskaltsisMortari A, Barnes SA, Xin X, Taylor DA: Sex-dependent attenuation of plaque growth after treatment with bone marrow mononuclear cells. Circ Res 2007, 101:1319-1327.

67. Gold B, Bergeron J, Achtermarcher-Truinfol M, Dean M: Human duplex sex determination PCR. Biotechniques 2001, 31:28-35.

68. Yu L, Martinez FD, Klimecki WT: Automated high-throughput sex-typing assay. Biotechniques 2004, 37:662-664.

69. Schneider JE, Wysocki CJ, Nyby J, Whitney G: Determining the sex of neonatal mice. Behav Res Meth Instr 1978, 10:105.

70. Waxman DJ, Dannan GA, Guengerich FP: Regulation of rat hepatic cytochrome P-450: age-dependent expression, hormonal imprinting, and xenobiotic inducibility of sex-specific isoenzymes. Biochemistry 1985, 24:4409-4417.

71. Csaba G, Torok O, Kovacs P: Permanence of the cell-to-cell transmission of insulin induced hormonal imprinting. Acta Physiol Hung 1990 75:111-116. 
72. Gros R, Ding Q, Sklar LA, Prossnitz EE, Arterburn JB, Chorazyczewski J, Feldman RD: GPR30 expression is required for the mineralocorticoid receptor-independent rapid vascular effects of aldosterone. Hypertension 2011, 57:442-451.

73. Deenadayalu VP, White RE, Stallone JN, Gao X, Garcia AJ: Testosterone relaxes coronary arteries by opening the large-conductance, calciumactivated potassium channel. Am J Physiol Heart Circ Physiol 2001, 281: H1720-H1727.

74. Rubio-Gayosso I, Garcia-Ramirez O, Gutierrez-Serdan R, Guevara-Balcazar G, Munoz-Garcia O, Morato-Cartajena T, Zamora-Garza M, Ceballos-Reyes G: Testosterone inhibits bradykinin-induced intracellular calcium kinetics in rat aortic endothelial cells in culture. Steroids 2002, 67:393-397.

75. Luczak ED, Barthe KKB, Stauffer BL, Konhilas JP, Cheung TH, Leinwand LA: Remodeling the cardiac transcriptional landscape with diet. Physiol Genomics 2011, 43:772-780.

76. Dodds WJ, Abelseth MK: Criteria for selecting the animal to meet the research need. Lab Anim Sci 1980, 30:460-465.

77. Kaplan JR, Manuck SB: Status, stress, and atherosclerosis: the role of environment and individual behavior. Ann N Y Acad Sci 1999, 896:145-161.

78. Kaplan JR, Manuck SB, Clarkson TB, Prichard RW: Animal models of behavioral influences on atherogenesis. Adv Behav Med 1985, 1:115-163.

79. Solskov L, Lofgren B, Pold R, Kristiansen SB, Nielsen T, Overstreet DH, Schmitz O, Botker HE, Lund S, Wegener G: Evaluation of the relationship between hyperinsulinaemia and myocardial ischaemia/reperfusion injury in a rat model of depression. Clin Sci (Lond) 2010, 118:259-267.

80. Hildreth CM, Padley JR, Pilowsky PM, Goodchild AK: Impaired serotonergic regulation of heart rate may underlie reduced baroreflex sensitivity in an animal model of depression. Am J Physiol Heart Circ Physiol 2008, 294 H474-480.

81. Yeh S, Tsai MY, Xu Q, Mu XM, Lardy H, Huang KE, Lin H, Yeh SD, Altuwaijri S, Zhou X, Xing L, Boyce BF, Hung MC, Zhang S, Gan L, Chang C: Generation and characterization of androgen receptor knockout (ARKO) mice: an in vivo model for the study of androgen functions in selective tissues. Proc Natl Acad Sci USA 2002, 99:13498-13503.

82. Lin TH, Yeh S, Chang C: Tissue-specific knockout of androgen receptor in mice. Methods Mol Biol 2011, 776:275-293.

83. Arias-Loza PA, Jazbutyte $V$, Pelzer T: Genetic and pharmacologic strategies to determine the function of estrogen receptor alpha and estrogen receptor beta in cardiovascular system. Gend Med 2008, 5(Suppl A): S34-45.

84. Korach KS, Couse JF, Curtis SW, Washburn TF, Lindzey J, Kimbro KS, Eddy EM, Migliaccio S, Snedeker SM, Lubahn DB, Schomberg DW, Smith EP: Estrogen receptor gene disruption: molecular characterization and experimental and clinical phenotypes. Recent Prog Horm Res 1996, 51:159-186.

85. Kerkhofs S, Denayer S, Haelens A, Claessens F: Androgen receptor knockout and knock-in mouse models. J Mol Endocrinol 2009, 42:11-17.

86. De Gendt K, Verhoeven G: Tissue- and cell-specific functions of the androgen receptor revealed through conditional knockout models in mice. Mol Cell Endocrinol .

87. Libby P, Ridker PM, Hansson GK: Progress and challenges in translating the biology of atherosclerosis. Nature 2011, 473:317-325.

88. Rauscher FM, Goldschmidt-Clermont PJ, Davis BH, Wang T, Gregg D, Ramaswami P, Pippen AM, Annex BH, Dong C, Taylor DA: Aging, progenitor cell exhaustion, and atherosclerosis. Circulation 2003, 108:457-463.

89. Arnold AP, Chen X: What does the "four core genotypes" mouse model tell us about sex differences in the brain and other tissues? Front Neuroendocrinol 2009, 30:1-9.

90. Rapp JP: Dahl salt-susceptible and salt-resistant rats. A review. Hypertension 1982, 4:753-763.

91. Hinojosa-Laborde C, Lange DL, Haywood JR: Role of female sex hormones in the development and reversal of Dahl hypertension. Hypertension 2000, 35:484-489.

92. Yanes LL, Sartori-Valinotti JC, lliescu R, Romero DG, Racusen LC, Zhang H, Reckelhoff JF: Testosterone-dependent hypertension and upregulation of intrarenal angiotensinogen in Dahl salt-sensitive rats. Am J Physiol Renal Physiol 2009, 296:F771-779.
93. Reckelhoff JF, Zhang H, Granger JP: Testosterone exacerbates hypertension and reduces pressure-natriuresis in male spontaneously hypertensive rats. Hypertension 1998, 31:435-439.

94. Xue B, Pamidimukkala J, Hay M: Sex differences in the development of angiotensin II-induced hypertension in conscious mice. Am J Physiol Heart Circ Physiol 2005, 288:H2177-2184.

95. Sartori-Valinotti JC, Iliescu R, Yanes LL, Dorsett-Martin W, Reckelhoff JF: Sex differences in the pressor response to angiotensin II when the endogenous renin-angiotensin system is blocked. Hypertension 2008, 51:1170-1176.

96. Hoyer PB, Devine PJ, Hu X, Thompson KE, Sipes IG: Ovarian toxicity of 4vinylcyclohexene diepoxide: a mechanistic model. Toxicol Pathol 2001, 29:91-99.

97. Van Kempen TA, Milner TA, Waters EM: Accelerated ovarian failure: a novel, chemically induced animal model of menopause. Brain Res 2011, 1379:176-187.

98. Mark-Kappeler CJ, Sen N, Lukefahr A, McKee L, Sipes IG, Konhilas J, Hoyer PB: Inhibition of ovarian KIT phosphorylation by the ovotoxicant 4-vinylcyclohexene diepoxide in rats. Biol Reprod 2011, 85:755-762.

99. Keating AF, Fernandez SM, Mark-Kappeler CJ, Sen N, Sipes IG, Hoyer PB: Inhibition of PIK3 signaling pathway members by the ovotoxicant 4vinylcyclohexene diepoxide in rats. Biol Reprod 2011, 84:743-751.

100. Wright LE, Christian PJ, Rivera Z, Van Alstine WG, Funk JL, Bouxsein ML, Hoyer PB: Comparison of skeletal effects of ovariectomy versus chemically induced ovarian failure in mice. J Bone Miner Res 2008, 23:1296-1303.

101. Wright LE, Frye JB, Lukefahr AL, Marion SL, Hoyer PB, Besselsen DG, Funk JL: 4-Vinylcyclohexene diepoxide (VCD) inhibits mammary epithelial differentiation and induces fibroadenoma formation in female Sprague Dawley rats. Reprod Toxicol 2011, 32:26-32.

102. Davison SL, Bell R, Donath S, Montalto JG, Davis SR: Androgen levels in adult females: changes with age, menopause, and oophorectomy. J Clin Endocrinol Metab 2005, 90:3847-3853.

103. Adashi EY: The climacteric ovary as a functional gonadotropin-driven androgen-producing gland. Fertil Steril 1994, 62:20-27.

104. Perusquia M, Stallone JN: Do androgens play a beneficial role in the regulation of vascular tone? Nongenomic vascular effects of testosterone metabolites. Am J Physiol Heart Circ Physiol 2010, 298: H1301-1307.

105. Appt SE, Clarkson TB, Hoyer PB, Kock ND, Goode AK, May MC, Persyn JT, Vail NK, Ethun KF, Chen H, Sen N, Kaplan JR: Experimental induction of reduced ovarian reserve in a nonhuman primate model (Macaca fascicularis). Comp Med 2010, 60:380-388.

106. Rivera Z, Christian PJ, Marion SL, Brooks HL, Hoyer PB: Steroidogenic capacity of residual ovarian tissue in 4-vinylcyclohexene diepoxidetreated mice. Biol Reprod 2009, 80:328-336.

107. Langrish JP, Mills NL, Bath LE, Warner P, Webb DJ, Kelnar CJ, Critchley HO, Newby DE, Wallace WH: Cardiovascular effects of physiological and standard sex steroid replacement regimens in premature ovarian failure. Hypertension 2009, 53:805-811.

108. Umetani M, Domoto H, Gormley AK, Yuhanna IS, Cummins CL, Liverman AB, Javitt NB, Shaul PW, Mangelsdorf DJ: 27-Hydroxycholesterol is an endogenous selective estrogen receptor modulator that inhibits the cardiovascular effects of estrogen. Nat Med 2007, 13:1185-1192.

109. Shockley KR, Witmer D, Burgess-Herbert SL, Paigen B, Churchill GA: Effects of atherogenic diet on hepatic gene expression across mouse strains. Physiol Genomics 2009, 39:172-182.

110. Korstanje R, Li R, Howard T, Kelmenson P, Marshall J, Paigen B, Churchill G: Influence of sex and diet on quantitative trait loci for $\mathrm{HDL}$ cholesterol levels in an SM/J by NZB/BINJ intercross population. J Lipid Res 2004, 45:881-888.

111. Bevan JA: Sites of transition between functional systemic and cerebral arteries of rabbits occur at embryological junctional sites. Science 1979, 204:635-637.

112. Bode-Boger SM, Boger RH, Kienke S, Bohme M, Phivthong-ngam L, Tsikas D, Frolich JC: Chronic dietary supplementation with I-arginine inhibits platelet aggregation and thromboxane $A_{2}$ synthesis in hypercholesterolaemic rabbits in vivo. Cardiovasc Res 1998, 37:756-764.

113. Boger RH, Bode-Boger SM, Kienke S, Stan AC, Nafe R, Frolich JC: Dietary Iarginine decreases myointimal cell proliferation and vascular monocyte accumulation in cholesterol-fed rabbits. Atherosclerosis 1998, 136:67-77. 
114. Finta KM, Fischer MJ, Lee L, Gordon D, Pitt B, Webb RC: Ramipril prevents impaired endothelium-dependent relaxation in arteries from rabbits fed an atherogenic diet. Atherosclerosis 1993, 100:149-156.

115. Gisclard V, Flavahan NA, Vanhoutte PM: Alpha-adrenergic responses of blood vessels of rabbits after ovariectomy and administration of $17 \beta$ estradiol. J Pharmacol Exper Ther 1987, 240:446-470.

116. Kanazawa K, Kawashima S, Mikami S, Miwa Y, Hirata K, Suematsu M, Hayashi Y, Itoh H, Yokoyama M: Endothelial constitutive nitric oxide synthase protein and mRNA increased in rabbit atherosclerotic aorta despite impaired endothelium-dependent vascular relaxation. Am J Pathol 1996, 148:1949-1956.

117. Langille BL, Reidy MA, Kline RL: Injury and repair of endothelium at sites of flow disturbances near abdominal aortic coarctation in rabbits. Arteriosclerosis 1986, 6:146-154.

118. Verbeuren TJ, Jordaens FH, Zonnekeyn LL, VanHove CE, Coene M-C, Herman AG: Effect of hypercholesterolemia on vascular reactivity in the rabbit. I. Endothelium-dependent and endothelium-independent contractions and relaxations in isolated arteries of control and hypercholesterolemic rabbits. Circ Res 1986, 58:552-564.

119. Fong IW, Chiu B, Viira E, Fong MW, Jang D, Mahony J: Rabbit model for Chlamydia pneumoniae infection. J Clin Microbiol 1997, 35:48-52.

120. Zheng B, Zheng T, Wang L, Chen X, Shi C, Zhao S: Aminoguanidine inhibition of iNOS activity ameliorates cerebral vasospasm after subarachnoid hemorrhage in rabbits via restoration of dysfunctional endothelial cells. J Neurol Sci 2010, 295:97-103.

121. Lotz C, Lazariotto M, Redel A, Smul TM, Stumpner J, Blomeyer C, TischerZeitz T, Schmidt J, Pociej J, Roewer N, Kehl F, Lange M: Activation of peroxisome-proliferator-activated receptors alpha and gamma mediates remote ischemic preconditioning against myocardial infarction in vivo. Exp Biol Med (Maywood) 2011, 236:113-122.

122. Raphael J, Gozal Y, Navot N, Zuo Z: Hyperglycemia inhibits anestheticinduced postconditioning in the rabbit heart via modulation of phosphatidylinositol-3-kinase/Akt and endothelial nitric oxide synthase signaling. J Cardiovasc Pharmacol 2010, 55:348-357.

123. Chobanian AV, Haudenschild CC, Nickerson C, Drago R: Antiatherogenic effect of captopril in the Watanabe heritable hyperlipidemic rabbit. Hypertension 1990, 15:327-331.

124. Kolodgie FD, Virmani R, Rice HE, Mergner WJ: Vascular reactivity during the progression of atherosclerotic plaque. A study in Watanabe heritable hyperlipidemic rabbits. Circ Res 1990, 66:1112-1126.

125. Bjarnason NH, Haarbo J, Byrjalsen I, Kauffman RF, Christiansen C: Reloxifene inhibits aortic accumulation of cholesterol in ovariectomized, cholesterol-fed rabbits. Circulation 1998, 96:1964-1969.

126. Cayatte AJ, Palacino JJ, Horten K, Cohen RA: Chronic inhibition of nitric oxide production accelerates neointima formation and impairs endothelial function in hypercholesterolemic rabbits. Atheroscler Thromb 1994, 14:753-759.

127. Krasinski K, Spyridopoulos I, Asahara T, van der Zee R, Isner JM, Losordo DW: Estradiol accelerates functional endothelial recovery after arterial injury. Circulation 1997, 95:1768-1772.

128. Miller VM, Aarhus LL, Vanhoutte PM: Effects of estrogens on adrenergic and endothelium-dependent responses in the ovarian artery of the rabbit. In Proceedings of the Second International Symposium on Resistance Arteries. Edited by: Halpern W, Brayden JE, McLaughlin M, Osol G, Pegram BL, Mackey K. Ithaca, NY: Perinatology Press; 1988:136-145.

129. Gisclard V, Miller VM, Vanhoutte PM: Effect of $17 \beta$-estradiol on endothelium-dependent responses in the rabbit. J Pharmacol Exper Ther 1988, 244:19-22.

130. Gerova M, Holecyova A, Kristek F, Fizel A, Fizel'ova A: Remodelling and functional alterations of the rabbit coronary artery in volume overloaded heart. Cardiovasc Res 1993, 27:2005-2010.

131. Heusch G, Guth BD, Seitelberger R, Ross J Jr: Attenuation of exerciseinduced myocardial ischemia in dogs with recruitment of coronary vasodilator reserve by nifedipine. Circulation 1987, 75:482-490.

132. Atkins BZ, Hueman MT, Meuchel JM, Cottman MJ, Hutcheson KA, Taylor DA: Myogenic cell transplantation improves in vivo regional performance in infarcted rabbit myocardium. J Heart Lung Transplant 1999, 18:1173-1180.

133. Emani SM, Ellis MJ, Dibernardo LR, Colgrove S, Glower DD, Taylor DA: Systolic contraction within aneurysmal rabbit myocardium following transplantation of autologous skeletal myoblasts. J Surg Res 2006, 135:202-208.
134. Taylor DA, Atkins BZ, Hungspreugs P, Jones TR, Reedy MC, Hutcheson KA, Glower DD, Kraus WE: Regenerating functional myocardium: improved performance after skeletal myoblast transplantation. Nat Med 1998, 4:929-933.

135. Davidson J, Spreadbury D: Nutrition of the New Zealand white rabbit. Proc Nutr Soc 1975, 34:75-83.

136. Karpuzoglu E, Ahmed SA: Estrogen regulation of nitric oxide and inducible nitric oxide synthase (iNOS) in immune cells: implications for immunity, autoimmune diseases, and apoptosis. Nitric Oxide 2006, 15:177-186.

137. Libby P: Inflammation in atherosclerosis. Nature 2002, 420:868-874.

138. Miller AP, Chen YF, Xing D, Feng W, Oparil S: Hormone replacement therapy and inflammation: interactions in cardiovascular disease. Hypertension 2003, 42:657-663.

139. Miller VM, Jayachandran M, Hashimoto K, Heit JA, Owen WG: Estrogen, inflammation, and platelet phenotype. Gender Med 2008, 5:S91-S102.

140. Gandolfi F, Vanelli A, Pennarossa G, Rahaman M, Acocella F, Brevini TA: Large animal models for cardiac stem cell therapies. Theriogenology 2011, 75:1416-1425.

141. Reckelhoff JF: Age-related changes in renal hemodynamics in female rats: role of multiple pregnancy and NO. Am J Physiol 1997, 272: R1985-1989.

142. Baylis C: Immediate and long-term effects of pregnancy on glomerular function in the SHR. Am J Physiol 1989, 257:F1140-1145.

143. Donald DE, Ferguson DA: Study of the sympathetic vasoconstrictor nerves to the vessels of the dog hind limb. Circ Res 1970, 26:171-184.

144. Hintze TH, Vatner SF: Reactive dilation of large coronary artereis in conscious dogs. Circ Res 1984, 54:50-57.

145. Murray PA, Lavallee M, Vatner SF: Alpha-adrenergic-mediated reduction in coronary blood flow secondary to carotid chemoreceptor reflex activation in conscious dogs. Circ Res 1984, 54:96-106.

146. Sessa WC, Pritchard K, Seyedi N, Wang J, Hintze TH: Chronic exercise in dogs increases coronary vascular nitric oxide production and endothelial cell nitric oxide synthase gene expression. Circ Res 1994, 74:349-353.

147. Broten TP, Miyashiro JK, Moncada S, Feigl EO: Role of endothelium-derived relaxing factor in parasympathetic coronary vasodilation. Am J Physiol 1992, 262:H1579-H1584.

148. Cohen RA, Shepherd JT, Vanhoutte PM: Prejunctional and postjunctional actions of endogenous norepinephrine at the sympathetic neuroeffector junction in canine coronary arteries. Circ Res 1983, 52:16-25.

149. Redfield M, Edwards B, McGoon M, Heublein D, Aarhus LL, Burnett JC Jr: Failure of atrial natriuretic factor to increase with volume expansion in acute and chronic congestive heart failure in the dog. Circulation 1989, 80:651-657.

150. Leri A, Liu Y, Malhotra A, Li Q, Stiegler P, Claudio PP, Giordano A, Kajstura J, Hintze TH, Anversa P: Pacing-induced heart failure in dogs enhances the expression of p53 and p53-dependent genes in ventricular myocytes. Circulation 1998, 97:194-203.

151. DeMey JG, Claeys M, Vanhoutte PM: Endothelium-dependent inhibitory effects of acetylcholine, adenosine triphosphate, thrombin and arachidonic acid in the canine femoral artery. J Pharmacol Exper Thera 1982, 222:166-173.

152. Miller VM, Vanhoutte PM: Progesterone and modulation of endotheliumdependent responses in canine coronary arteries. Am J Physiol 1991, 261: R1022-R1027.

153. Miller VM, Burnett JC Jr: Modulation of nitric oxide and endothelin by chronic increases in blood flow in canine femoral arteries. Am J Physiol 1992, 263:H103-H108.

154. Miller VM, Marcelon G, Vanhoutte PM: Progesterone augments the venoconstrictor effect of Ruscus without altering adrenergic reactivity. Phlebology 1992, 6:261-268.

155. Chatrath R, Ronningen $K L$, LaBreche $P$, Severson $S R$, Jayachandran $M$, Bracamonte MP, Miller VM: Effect of puberty on coronary arteries from female pigs. J Appl Physiol 2003, 95:1672-1680.

156. Chatrath $R$, Ronningen $K L$, Severson $S R$, LaBreche $P$, Jayachandran $M$, Bracamonte MP, Miller VM: Endothelium-dependent responses in coronary arteries are changed with puberty in male pigs. Am J Physiol: Heart Circ Physiol 2003, 285:H1168-H1176.

157. Shimokawa H, Aarhus LL, Vanhoutte PM: Porcine coronary arteries with regenerated endothelium have a reduced endothelium-dependent 
responsiveness to aggregating platelets and serotonin. Circ Res 1987, 61:256-270.

158. Payne GA, Borbouse L, Kumar S, Neeb Z, Alloosh M, Sturek M, Tune JD: Epicardial perivascular adipose-derived leptin exacerbates coronary endothelial dysfunction in metabolic syndrome via a protein kinase Cbeta pathway. Arterioscler Thromb Vasc Biol 2010, 30:1711-1717.

159. Neeb ZP, Edwards JM, Alloosh M, Long X, Mokelke EA, Sturek M: Metabolic syndrome and coronary artery disease in Ossabaw compared with Yucatan swine. Comp Med 2010, 60:300-315.

160. Dyson MC, Alloosh M, Vuchetich JP, Mokelke EA, Sturek M: Components of metabolic syndrome and coronary artery disease in female Ossabaw swine fed excess atherogenic diet. Comp Med 2006, 56:35-45.

161. Kaplan JR, Adams MR, Clarkson TB, Manuck SB, Shively CA, Williams JK: Psychosocial factors, sex differences, and atherosclerosis: lessons from animal models. Psychosom Med 1996, 58:598-611.

162. Bond MG, Bullock BC, Bellinger DA, Hamm TE: Myocardial infarction in a large colony of nonhuman primates with coronary artery atherosclerosis. Am J Pathol 1980, 101:675-692.

163. Kaplan JR, Manuck SB: Ovarian dysfunction, stress, and disease: a primate continuum. ILAR J 2004, 45:89-115.

164. Hamm TE Jr, Kaplan JR, Clarkson TB, Bullock BC: Effects of gender and social behavior on the development of coronary artery atherosclerosis in cynomolgus macaques. Atherosclerosis 1983, 48:221-233.

165. Kaplan JR, Manuck SB: Ovarian dysfunction and the premenopausal origins of coronary heart disease. Menopause 2008, 15:768-776.

166. Berga SL, Mortola JF, Girton L, Suh BY, Laughlin G, Pham P, Yen SSC: Neuroendocrine aberrations in women with functional hypothalamic amenorrhea. J Clin Endocrinol Metab 1989, 68:301 308.

167. Adams MR, Kaplan JR, Clarkson TB, Koritnik DR: Ovariectomy, social status, and atherosclerosis in cynomolgus monkeys. Arteriosclerosis 1985, 5:192-200.

168. Kaplan JR, Adams MR, Anthony MS, Morgan TM, Manuck SB, Clarkson TB: Dominant social status and contraceptive hormone treatment inhibit atherogenesis in premenopausal monkeys. Arterioscler Thromb Vasc Biol 1995, 15:2094-2100.

169. Kaplan JR, Manuck SB, Anthony MS, Clarkson TB: Premenopausal social status and hormone exposure predict postmenopausal atherosclerosis in female monkeys. Obstet Gynecol 2002, 99:381-388.

170. Clarkson TB, Anthony MS, Morgan TM: Inhibition of postmenopausal atherosclerosis progression: a comparison of the effects of conjugated equine estrogens and soy phytoestrogens. J Clin Endocrinol Metab 2001, 86:41-47.

171. Adams MR, Kaplan JR, Manuck SB, Koritnik DR, Parks JS, Wolfe MS, Clarkson TB: Inhibition of coronary artery atherosclerosis by $17-\beta-$ estradiol in ovariectomized monkeys. Lack of an effect of added progesterone. Arteriosclerosis 1990, 10:1051-1057.

172. Clarkson TB: Estrogen effects on arteries vary with stage of reproductive life and extent of subclinical atherosclerosis progression. Menopause 2007, 14:373-384.

173. Anthony MS, Clarkson TB: Does extent of pretreatment atherosclerosis influence the effects of conjugated equine estrogens on atherosclerosis progression? J Am Coll Cardiol 2002, 39(Suppl A):248A.

174. Evans AM: Age at puberty and first litter size in early and late paired rats. Biol Reprod 1986, 34:322-323.

175. Felicio LS, Nelson JF, Finch CE: Longitudinal studies of estrous cyclicity in aging C57BL/6J mice: II. Cessation of cyclicity and the duration of persistent vaginal cornification. Biol Reprod 1984, 31:446-453.

176. Fortepiani LA, Zhang H, Racusen L, Roberts LJn, Reckelhoff JF: Characterization of an animal model of postmenopausal hypertension in spontaneously hypertensive rats. Hypertension 2003, 41:460-463.

177. Tower AM, Trinward A, Lee K, Joseph $L$, Jacobson HI, Bennett JA, Andersen TT: AFPep, a novel drug for the prevention and treatment of breast cancer, does not disrupt the estrous cycle or fertility in rats. Oncol Rep 2009, 22:49-56.

178. Baylis C: Glomerular ultrafiltration in the pseudopregnant rat. Am J Physiol 1982, 234:F300-F305.

179. Swingle WW, Seay P, Perlmutt J, Collins EJ, Barlow G, Fedor EJ: An experimental study of pseudopregnancy in rat. Am J Physiol 1951, 167:586-592.
180. Butcher RL, Collins WE, Fugo NW: Plasma concentrations of LH, FSH, prolactin, protesterone and estradiol-17 $\beta$ through the 4-day estrous cycle of the rat. Endocrinol 1974, 94:1704-1708.

181. Teixeira Gomes RC, Verna C, Nader HB, dos Santos Simoes R, Dreyfuss UL, Martins JR, Baracat EC, de Jesus Simoes M, Soares JM Jr: Concentration and distribution of hyaluronic acid in mouse uterus throughout the estrous cycle. Fertil Steril 2009, 92:785-792.

182. Kramer PR, Bellinger LL: The effects of cycling levels of $17 \beta$-estradiol and progesterone on the magnitude of temporomandibular joint-induced nociception. Endocrinology 2009, 150:3680-3689.

183. Ferin M, Jewelewicz R, Warren M: The Menstrual Cycle: Physiology, Reproductive Disorders, and Infertility. 1 edition. Oxford, UK: Oxford University Press; 1993.

184. Kaplan JR, Chen H, Appt SE, Lees CJ, Franke AA, Berga SL, Wilson ME, Manuck SB, Clarkson TB: Impairment of ovarian function and associated health-related abnormalities are attributable to low social status in premenopausal monkeys and not mitigated by a high-isoflavone soy diet. Hum Reprod 2010, 25:3083-3094.

185. Adams MR, Williams JK, Kaplan JR: Effects of androgens on coronary artery atherosclerosis and atherosclerosis-related impairment of vascular responsiveness. Arterioscler Thromb 1995, 15:562-570.

186. Jenkins C, Salisbury R, Ely D: Castration lowers and testosterone restores blood pressure in several rat strains on high sodium diets. Clin Exp Hypertens 1994, 16:611-625.

187. Hotchkiss CE, Stavisky R, Nowak J, Brommage R, Lees CJ, Kaplan J: Levormeloxifene prevents increased bone turnover and vertebral bone loss following ovariectomy in cynomolgus monkeys. Bone 2001, 29:7-15.

188. O'Brien Z, Post N, Brown M, Madan A, Coon T, Luo R, Kohout TA: Validation and application of a liquid chromatography-tandem mass spectrometric method for the simultaneous determination of testosterone and dihydrotestosterone in rat prostatic tissue using a 96-well format. $J$ Chromatogr B Analyt Technol Biomed Life Sci 2009, 877:3515-3521.

189. Brundu B, Loucks TL, Adler LJ, Cameron JL, Berga SL: Increased cortisol in the cerebrospinal fluid of women with functional hypothalamic amenorrhea. J Clin Endocrinol Metab 2006, 91:1561-1565.

190. Abiola O, Angel JM, Avner P, Bachmanov AA, Belknap JK, Bennett B, Blankenhorn EP, Blizard DA, Bolivar V, Brockmann GA, Buck KJ, Bureau JF, Casley WL, Chesler EJ, Cheverud JM, Churchill GA, Cook M, Crabbe JC, Crusio WE, Darvasi A, de Haan G, Dermant P, Doerge RW, Elliot RW, Farber CR, Flaherty L, Flint J, Gershenfeld H, Gibson JP, Gu J: The nature and identification of quantitative trait loci: a community's view. Nat Rev Genet 2003, 4:911-916.

191. Paigen B, Plump AS, Rubin EM: The mouse as a model for human cardiovascular disease and hyperlipidemia. Curr Opin Lipidol 1994, 5:258-264.

192. Nikoh N, Duty A, Gibson G: Effects of population structure and sex on association between serotonin receptors and Drosophila heart rate. Genetics 2004, 168:1963-1974.

193. Isensee J, Ruiz Noppinger P: Sexually dimorphic gene expression in mammalian somatic tissue. Gend Med 2007, 4(Suppl B):S75-95.

194. Mahaney MC, Blangero J, Rainwater DL, Mott GE, Comuzzie AG, MacCluer JW, VandeBerg JL: Pleiotropy and genotype by diet interaction in a baboon model for atherosclerosis: a multivariate quantitative genetic analysis of HDL subfractions in two dietary environments. Arterioscler Thromb Vasc Biol 1999, 19:1134-1141.

195. Tejero ME, Voruganti VS, Rodriguez-Sanchez IP, Proffitt JM, Blangero J, Cox LA, Mahaney MC, Rogers J, VandeBerg JL, Cole SA, Comuzzie AG: Genetics of variation in adiponectin in pedigreed baboons: evidence for pleiotropic effects on adipocyte volume and serum adiponectin. Heredity 2008, 100:382-389.

196. In Genetic Variants and Strains of the Laboratory Mouse.. 2 edition. Edited by: Lyon MF, Seale AG. Oxford, UK: Oxford University Press; 1989:

197. In Biology of the Laboratory Mouse.. 2 edition. Edited by: Green EL. New York, USA: Dover Publications, Inc.; 1966:.

198. Ernest S, Hosack A, O'Brien WE, Rosenblatt DS, Nadeau JH: Homocysteine levels in $\mathrm{A} / \mathrm{J}$ and $\mathrm{C} 57 \mathrm{BL} / 6 \mathrm{~J}$ mice: genetic, diet, gender, and parental effects. Physiol Genomics 2005, 21:404-410.

199. Hoit BD, Kiatchoosakun S, Restivo J, Kirkpatrick D, Olszens K, Shao H, Pao $\mathrm{YH}$, Nadeau $\mathrm{JH}$ : Naturally occurring variation in cardiovascular traits among inbred mouse strains. Genomics 2002, 79:679-685. 
200. Mouse Phenotype Database Integration Consortium, Hancock JM, Adams NC, Aidinis V, Blake A, Bogue M, Brown SD, Chesler EJ, Davidson D, Duran C, Eppig JT, Gailus-Durner V, Gates H, Gkoutos GV, Greenaway S, Hrabé de Angelis $M$, Kollias $G$, Leblanc $S$, Lee $K$, Lengger C, Maier $H$, Mallon AM, Masuya H, Melvin DG, Müller W, Parkinson H, Proctor G, Reuveni E, Schofield P, Shukla A, et al: Mouse Phenotype Database Integration Consortium: integration [corrected] of mouse phenome data resources. Mamm Genome 2007, 18:157-163.

201. Kirby A, Kang HM, Wade CM, Cotsapas C, Kostem E, Han B, Furlotte N, Kang EY, Rivas M, Bogue MA, Frazer KA, Johnson FM, Beilharz EJ, Cox DR, Eskin E, Daly MJ: Fine mapping in 94 inbred mouse strains using a highdensity haplotype resource. Genetics 2010, 185:1081-1095.

202. Bennett BJ, Farber CR, Orozco L, Kang HM, Ghazalpour A, Siemers N, Neubauer M, Neuhaus I, Yordanova R, Guan B, Truong A, Yang WP, He A, Kayne P, Gargalovic P, Kirchgessner T, Pan C, Castellani LW, Kostem E, Furlotte N, Drake TA, Eskin E, Lusis AJ: A high-resolution association mapping panel for the dissection of complex traits in mice. Genome Res 2010, 20:281-290.

203. Twigger SN, Pruitt KD, Fernández-Suárez XM, Karolchik D, Worley KC, Maglott DR, Brown G, Weinstock G, Gibbs RA, Kent J, Birney E, Jacob HJ: What everybody should know about the rat genome and its online resources. Nat Genet 2008, 40:523-527.

204. Liu P, Vikis H, Lu Y, Wang D, You M: Large-scale in silico mapping of complex quantitative traits in inbred mice. PLoS One 2007, 2:e651.

205. Blake JA, Bult CJ, Kadin JA, Richardson JE, Eppig JT: The Mouse Genome Database (MGD): premier model organism resource for mammalian genomics and genetics. Nucleic Acids Res 2011, 39:D842-848.

206. Moreno C, Dumas P, Kaldunski ML, Tonellato PJ, Greene AS, Roman RJ, Cheng Q, Wang Z, Jacob HJ, Cowley AW Jr: Genomic map of cardiovascular phenotypes of hypertension in female Dahl S rats. Physiol Genomics 2003, 15:243-257.

207. Stoll M, Cowley AW Jr, Tonellato PJ, Greene AS, Kaldunski ML, Roman RJ, Dumas P, Schork NJ, Wang Z, Jacob HJ: A genomic-systems biology map for cardiovascular function. Science 2001, 294:1723-1726.

208. Mattson DL, Dwinell MR, Greene AS, Kwitek AE, Roman RJ, Jacob HJ, Cowley AW Jr: Chromosome substitution reveals the genetic basis of Dahl salt-sensitive hypertension and renal disease. Am J Physiol Renal Physiol 2008, 295:F837-842.

209. Nadeau JH, Singer JB, Matin A, Lander ES: Analysing complex genetic traits with chromosome substitution strains. Nat Genet 2000, 24:221-225.

210. Yazbek SN, Buchner DA, Geisinger JM, Burrage LC, Spiezio SH, Zentner GE, Hsieh CW, Scacheri PC, Croniger CM, Nadeau JH: Deep congenic analysis identifies many strong, context-dependent QTLs, one of which, Slc35b4, regulates obesity and glucose homeostasis. Genome Res 2011, 21:1065-1073.

211. Wang S, Yehya N, Schadt EE, Wang H, Drake TA, Lusis AJ: Genetic and genomic analysis of a fat mass trait with complex inheritance reveals marked sex specificity. PLoS Genet 2006, 2:e15.

212. Cheverud JM, Lawson HA, Fawcett GL, Wang B, Pletscher LS, A RF, Maxwell TJ, Ehrich TH, Kenney-Hunt JP, Wolf JB, Semenkovich CF: Dietdependent genetic and genomic imprinting effects on obesity in mice. Obesity (Silver Spring) 2011, 19:160-170.

213. Hager R, Cheverud JM, Leamy $\amalg$, Wolf JB: Sex dependent imprinting effects on complex traits in mice. BMC Evol Biol 2008, 8:303.

214. van Nas A, Ingram-Drake L, Sinsheimer JS, Wang SS, Schadt EE, Drake T, Lusis AJ: Expression quantitative trait loci: replication, tissue- and sexspecificity in mice. Genetics 2010, 185:1059-1068.

215. Arnold AP, van Nas A, Lusis AJ: Systems biology asks new questions about sex differences. Trends Endocrinol Metab 2009, 20:471-476.

216. Norgard EA, Lawson HA, Pletscher LS, Wang B, Brooks VR, Wolf JB, Cheverud JM: Genetic factors and diet affect long-bone length in the F34 LG,SM advanced intercross. Mamm Genome 2011, 22:178-196.

217. Aylor DL, Valdar W, Foulds-Mathes W, Buus RJ, Verdugo RA, Baric RS, Ferris MT, Frelinger JA, Heise M, Frieman MB, Gralinski LE, Bell TA, Didion JD, Hua K, Nehrenberg DL, Powell CL, Steigerwalt J, Xie Y, Kelada SN, Collins FS, Yang IV, Schwartz DA, Branstetter LA, Chesler EJ, Miller DR, Spence J, Liu EY, McMillan L, Sarkar A, Wang J: Genetic analysis of complex traits in the emerging Collaborative Cross. Genome Res 2011, 21:1213-1222.

218. Iraqi FA, Churchill G, Mott R: The Collaborative Cross, developing a resource for mammalian systems genetics: a status report of the Wellcome Trust cohort. Mamm Genome 2008, 19:379-381.
219. Mathes WF, Aylor DL, Miller DR, Churchill GA, Chesler EJ, de Villena FP, Threadgill DW, Pomp D: Architecture of energy balance traits in emerging lines of the Collaborative Cross. Am J Physiol Endocrinol Metab 2011, 300:E1124-1134.

220. Zucker I, Beery A: Males still dominate animal studies. Nature 2010, 465:690.

221. Steiner M: Serotonin, depression, and cardiovascular disease: sex-specific issues. Acta Physiol (Oxf) 2011, 203:253-258.

doi:10.1186/2042-6410-2-14

Cite this article as: Miller et al:: Strategies and methods to study sex differences in cardiovascular structure and function: a guide for basic scientists. Biology of Sex Differences 2011 2:14.

\section{Submit your next manuscript to BioMed Central and take full advantage of:}

- Convenient online submission

- Thorough peer review

- No space constraints or color figure charges

- Immediate publication on acceptance

- Inclusion in PubMed, CAS, Scopus and Google Scholar

- Research which is freely available for redistribution

Submit your manuscript at www.biomedcentral.com/submit
Biomed Central 